Article

\title{
Fusaricidins, Polymyxins and Volatiles Produced by Paenibacillus polymyxa Strains DSM 32871 and M1
}

\author{
Pascal Mülner ${ }^{1,2}$, Elisa Schwarz ${ }^{1}$, Kristin Dietel ${ }^{1}$, Stefanie Herfort ${ }^{3}$, Jennifer Jähne ${ }^{3}$, Peter Lasch ${ }^{3}$, \\ Tomislav Cernava ${ }^{2}$, Gabriele Berg ${ }^{2}$ and Joachim Vater ${ }^{3, *(D)}$ \\ 1 ABITEP GmbH, Glienicker Weg 185, 12489 Berlin, Germany; pascal.muelner@tugraz.at (P.M.); \\ Schwarz@abitep.de (E.S.); Dietel@abitep.de (K.D.) \\ 2 Institute of Environmental Biotechnology, Graz University of Technology, Petergasse 12, 8010 Graz, Austria; \\ tomislav.cernava@tugraz.at (T.C.); gabriele.berg@tugraz.at (G.B.) \\ 3 Robert Koch-Institut, ZBS6, Proteomics and Spectroscopy, Seestr 10, 13353 Berlin, Germany; \\ HerfortS@rki.de (S.H.); JaehneJ@rki.de (J.J.); LaschP@rki.de (P.L.) \\ * Correspondence: vatermj@web.de
}

check for updates

Citation: Mülner, P.; Schwarz, E.; Dietel, K.; Herfort, S.; Jähne, J.; Lasch, P.; Cernava, T.; Berg, G.; Vater, J. Fusaricidins, Polymyxins and Volatiles Produced by Paenibacillus polymyxa Strains DSM 32871 and M1. Pathogens 2021, 10, 1485. https:// doi.org/10.3390/pathogens10111485

Academic Editors: Huijun Wu and Xuewen Gao

Received: 18 October 2021

Accepted: 9 November 2021

Published: 15 November 2021

Publisher's Note: MDPI stays neutral with regard to jurisdictional claims in published maps and institutional affiliations.

Copyright: (c) 2021 by the authors. Licensee MDPI, Basel, Switzerland. This article is an open access article distributed under the terms and conditions of the Creative Commons Attribution (CC BY) license (https:/ / creativecommons.org/licenses/by/ $4.0 /)$.

\begin{abstract}
Paenibacilli are efficient producers of potent agents against bacterial and fungal pathogens, which are of great interest both for therapeutic applications in medicine as well as in agrobiotechnology. Lipopeptides produced by such organisms play a major role in their potential to inactivate pathogens. In this work we investigated two lipopeptide complexes, the fusaricidins and the polymyxins, produced by Paenibacillus polymyxa strains DSM 32871 and M1 by MALDI-TOF mass spectrometry. The fusaricidins show potent antifungal activities and are distinguished by an unusual variability. For strain DSM 32871 we identified numerous yet unknown variants mass spectrometrically. DSM 32871 produces polymyxins of type E (colistins), while M1 forms polymyxins P. For both strains, novel but not yet completely characterized polymyxin species were detected, which possibly are glycosylated. These compounds may be of interest therapeutically, because polymyxins have gained increasing attention as last-resort antibiotics against multiresistant pathogenic Gram-negative bacteria. In addition, the volatilomes of DSM 32781 and M1 were investigated with a GC-MS approach using different cultivation media. Production of volatile organic compounds (VOCs) was strain and medium dependent. In particular, strain M1 manifested as an efficient VOC-producer that exhibited formation of 25 volatiles in total. A characteristic feature of Paenibacilli is the formation of volatile pyrazine derivatives.
\end{abstract}

Keywords: P. polymyxa; bioactive peptides; volatiles; MALDI-TOF mass spectrometry; GC-MS

\section{Introduction}

Paenibacillus spp. are distinguished by a large arsenal of bioactive secondary metabolites, such as nonribosomally formed lipopeptides, lassopeptides, polyketides, lantibiotics and bacteriocines, which are of high importance both in agrobiotechnology and medicine [1-4]. They are efficient producers of potent agents against both bacterial and fungal pathogens. The most abundant bioactive compounds of these organisms are lipopeptides, which cover a broad range of structurally diverse linear and cyclic species with peptide chain lengths between 6 and 13 amino acids and manifold variations in their fatty acid chains. They comprise fusaricidins and the related LiF-antibiotics (cyclic lipohexapeptides connected with a guanidinilated ß-hydroxy fatty acid with chain lengths between 13-19 carbon atoms) [5-12], paenilipoheptins (cyclic lipoheptapeptides, ß-amino fatty acid) [13], octapeptins (cyclic lipooctapeptides, B-hydroxy fatty acid) [1,14], polypeptins (cyclic lipononapeptides, B-hydroxy fatty acid) [1,15], pelgipeptins (cyclic lipononapeptides, ß-hydroxy fatty acid) [1,16], polymyxins (cyclic lipodecapeptides, C8,9-unsubstituted fatty acids) [1,17], tridecapeptins (linear lipotridecapeptides, ß-hydroxy fatty acids) [1,18-20] and paenibacterins (cyclic lipotridecapeptides, pentadecanoic acid) [21,22]. A promising 
prospect for medical application of these agents is that some of them display strong activities against multidrug-resistant pathogens covering both Gram-negative as well as Gram-positive bacteria. Therefore, they may be a valuable resource for the development of novel antibiotics to overcome the increasing problem of antibiotic resistance. In particular, the exploitation of the bioactive agents produced by $P$. polymyxa may contribute to solve this insistent public health issue.

The present study is focused on Paenibacillus polymyxa strains, which are efficient plant growth-promoting rhizobacteria (PGPR) colonizing surfaces of plant roots in the rhizosphere [23-25]. They also appear as endophytes within the plant [26,27]. Such strains produce four classes of lipopeptides, the fusaricidins, paenilipoheptins, polymyxins and tridecaptins. All of them comprise numerous structural homologs. In particular, fusaricidins [10-12] show an unusual complexity of isoforms providing a large spectrum of closely related agents with graduated activities against fungal pathogens. In this work we investigated the fusaricidin and polymyxin complexes produced by P. polymyxa DSM 32871 in comparison to those formed by the well-characterized strain M1 as model organism. M1 is an efficient plant growth promoting rhizobacterium. Its complete genome was sequenced by Niu et al. [28] revealing nine gene clusters involved in nonribosomal synthesis of bioactive peptides and polyketides. DSM 32871 is a novel strain. Its genome sequence is not yet available.

Fusaricidins were discovered by Kakinuma et al. [5,6] and thereafter investigated by other authors in detail [7-9]. They provide a large reservoir of potent antifungal biocontrol agents against a broad array of phytopathogenic fungi, such as Fusarium strains [26,29], Rhizoctonia solani [25], Leptosphaeria maculans [30], Sclerotinia sclerotiorum [25] and Botrytis cinerea [25], for examples. They are commonly used to cure plant diseases, such as fusarium wilt of cucumber [29]; gibberella ear rot of maize [26]; blackleg disease of canola [30] or bacterial leaf blight in rice [31].

Polymyxins are cationic cyclic lipodecapeptides, which also appear as a family of closely related variants $[17,32]$. They are positively charged because of the free amino groups of five of their six 2,4-diaminobutyric acid (Dab) components. They are dissected into three characteristic structural elements. They are acylated at their N-terminal Dab residue either by S-6-methyl octameric acid or (S)-6-methyl heptanoic acid. Dab (1) is part of a linear tripeptide segment $\mathrm{Dab}(1)-\mathrm{Thr}(2)-\mathrm{Dab}(3)-$. Dab (4) is involved in formation of a heptapeptide ring by condensation of its free amino group with the carboxyl group of the C-terminal Thr (10). The heptapeptide ring harbors a variable motif at positions $\mathrm{R}(6)$ and $R(7)$. These residues appearing in D-configuration are specific for the polymyxin type and can therefore be used for the classification of these antibiotics. The therapeutically most important species are polymyxin B [17] and polymyxin E (colistin) [33-35]. Polymyxins E are produced by P. polymyxa DSM 32871. Here, positions 6 and 7 are occupied by two leucine residues, while for polymyxin B Leu (6) is replaced by Phe. The corresponding motif of polymyxin P produced by strain M1 is D-Phe-D-Thr [36,37]. Polymyxin B and E species showing numerous variations both in their fatty acid side chain as well as by amino acid substitutions in their peptide portion were extensively characterized by liquid chromatography electrospray ionization ion trap tandem mass spectrometry [37-40].

Biosynthesis of fusaricidins and polymyxins is accomplished nonribosomally at multifunctional protein templates. Fusaricidin formation is encoded by the fus gene cluster. Fusaricidin synthetase FusA, the gene product of the central fus $A$ gene, consists of six modules for activation and condensation of all six amino acid components forming the complete peptide chain of fusaricidin [10].

Gene clusters pmx responsible for the biosynthesis of polymyxins A, B, E and P were identified and sequenced from the genomes of their producer organisms [41-44]. In each case $p m x$ comprises genes for three peptide synthetases and two putative ABC transporters. Polymyxin synthetase is a complex of three multienzymes PmxA, B and E. PmxE is a five module multienzyme, activating and condensing the first five amino acid components of polymyxins forming the pentapeptide intermediate L-Dab-L-Thr-D-Dab-L-Dab-L-Dab- 
PmxA contains four modules specific for the next four amino acid substrates extending the growing peptide chain until the nonapeptide. Finally, polymyxin synthesis is terminated by PmxB containing the module specific for the C-terminal L-Thr residue together with a thioester domain. The structural complexity of lipopeptides, such as fusaricidins and polymyxins, is not obvious from the gene level, but depends on the relatively high substrate variability at the reaction centers of the involved NRPS producer multienzymes.

Polymyxins are in focus as last resort antibiotics against multiresistant Gram-negative pathogens, such as the majority of Enterobacteriaceae, K. pneumoniae, A. baumannii or P. aeruginosa $[45,46]$. The therapeutic application of polymyxins certainly is the most important public interest, but beyond this there are also promising aspects for their usage as biocontrol agents in plant biotechnology. Recently, polymyxin P was demonstrated to suppress phytopathogenic Erwinia spp., the causative pathogen of fire blight and soft rot diseases [44].

Another class of attractive microbial secondary metabolites exhibiting manifold important activities are volatile organic compounds (VOCs), which display high chemical diversity [47-49]. They gain increasing attention particularly concerning plant growth promotion [50-52], biocontrol against bacterial and fungal pathogens [51,52] and induction of systemic resistance against phytopathogens [53-55].

In our work we performed comprehensive studies on the variety of the fusaricidin and polymyxin lipopeptide complexes produced by P. polymyxa DSM 32871 and M1 by MALDI-TOF mass spectrometry. These antifungal and antibacterial agents are of high relevance for inactivation of both human and plant pathogens. In addition, the diversity of volatile organic compounds (VOCs) released by these strains was studied with a specific headspace GC-MS analysis method under different growth conditions.

\section{Results}

In this work we investigated the biosynthetic potential of the Paenibacillus polymyxa strain DSM 32871. Its product pattern was compared with that of the well characterized M1 strain [10,11], which was implemented as a model strain. To explore the antimicrobial capacity of these strains we investigated their biosynthetic products by MALDI-TOF mass spectrometry in a time and space dependent fashion. We focused on two lipopeptide complexes, the fusaricidins and the polymyxins, as well as their volatiles which facilitate long-range interactions with plants and their native microbiota in the rhizosphere.

For this purpose, DSM 32871 and M1 were grown in various cultivation media (Landy, LOP, LB, TSA and GSC). Samples were taken at growth times of 12; 24; $48 ; 72$ and $96 \mathrm{~h}$ to investigate the time profile of the production of the tested bioactive compounds and to determine their specific location. It was assessed whether they were residing in the cell or at the outer cell wall, or if they were released into the cultivation media.

Figure 1 shows MALDI-TOF mass spectra of surface extracts (Figure 1A,C) and culture filtrates (Figure 1B,D) of DSM 32871 and M1 in the mass range of 800-2000 Da indicating three lipopeptide complexes, the fusaricidins, polymyxins and tridecaptins. The strains were cultivated in the LOP medium. Surface extracts were prepared by extraction of cell material obtained from agar plates with 50\% ACN/0.1\% TFA. Fusaricidins and tridecaptins preferentially were found attached to the outer surface of the Paenibacillus strains, while the polymyxins were mainly released into the cultivation media. At growth times higher than $48 \mathrm{~h}$ fusaricidins were also enriched in the culture filtrates.

In particular, the fusaricidin complex is distinguished by an unusually high variability [11]. Its composition depends on the growth medium as is apparent from Supplementary Materials (Figure S1) for cultivation of DSM 32871 and M1 in the Landy/LOP and LB medium. Interestingly, for DSM 32871 grown in the Landy or LOP medium in the MALDITOF mass spectra (Figures S1A and 2A), fusaricidins A and B with molecular masses of $m / z=883.9$ and 897.9 and their derivatives at $m / z=954.9$ and 968.9 differing from the parent ions by a mass difference of 71 Da were prevalent, while for DSM 32871 grown in the 
LB medium and for M1 cultivated in both the Landy/LOP and the LB media fusaricidins A, B, C $(m / z=947.9)$ and $\mathrm{D}(m / z=961.9)$ were the prominent species.
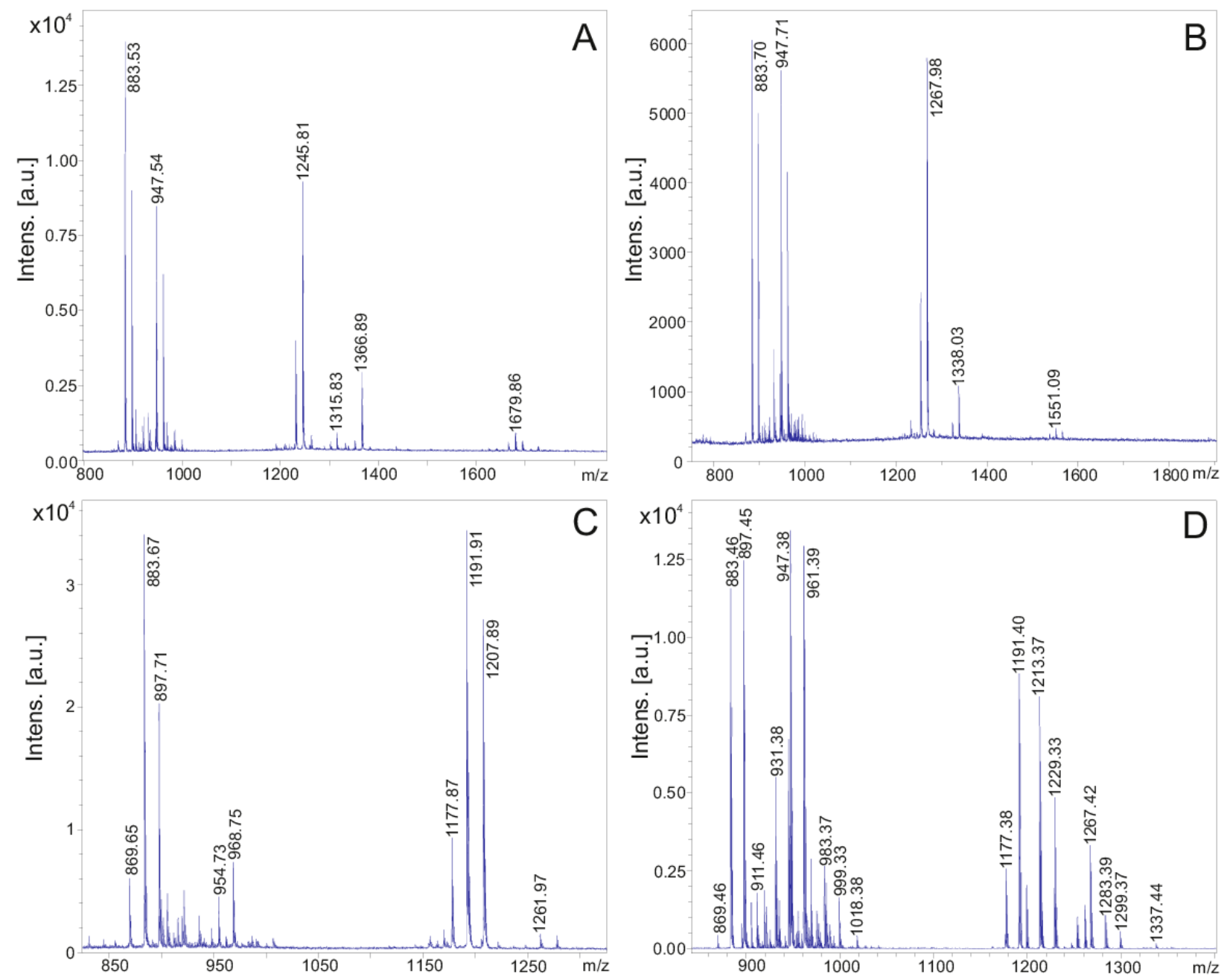

Figure 1. MALDI-TOF mass spectra of surface extracts of P. polymyxa DSM 32871 (A) and M1 (B) after growth for $72 \mathrm{~h}$ on Landy agar plates and in the culture filtrates after growing these strains in the LOP medium (C,D) in the mass range of $m / z=800-2000 \mathrm{Da}$. Surface extracts were obtained by extraction of cell material with $50 \%$ acetonitrile/0.1\% trifluoroacetic acid.

The culture filtrate of DSM 32871 grown for $48 \mathrm{~h}$ in the LOP medium (Figure 2A) was fractionated by reversed phase HPLC on a 300 SB-C 8 Zorbax column. The chromatogram in Figure 2B shows product fractionation in fractions 20 to 30. MALDI-TOF mass spectra of aliquots of fractions 22-30 is shown in Supplementary Materials (Figure S2A-K) demonstrating the separation of the produced compounds. Fusaricidins are the main products of DSM 32871. They were distributed among a broad range in fractions 22-30. Polymyxins appeared in fractions 22 and 23. Tridecaptins were found in fractions 28-30.

The fusaricidins produced by P. polymyxa DSM 32871 are summarized in Table 1 . They comprise the well-known fusaricidins A-F $[5,6,10,11]$. In addition, fusaricidins were found at $m / z=869.53$ and 855.51 which could be derived from fusaricidin A either by substitution of Thr (1) or both threonines in positions 1 and 4 by serines, respectively. Apparently, three series of new fusaricidin species were detected. For DSM 32871 the occurrence of derivatives of all these fusaricidins was characteristic, which differ from their parent ions by a mass difference of $71 \mathrm{Da}$ indicating modification by attachment of an alanine residue. These variants were among the dominating species in the mass spectra of DSM 32871. In addition, for this strain two other yet unknown fusaricidins with molecular masses of 
$m / z=899.6$ and 913.6 were found. They are related to fusaricidins A and B with a mass difference of $16 \mathrm{Da}$, indicating a hydroxylation of these species. In addition, for these new fusaricidins +71 -derivatives $(m / z=970.5$ and 984.5) appeared. All these variants were either not found or are present in only low amount in samples of the reference strain M1. The structure of all these new fusaricidins were investigated by fragment analysis using LIFT-MALDI-TOF/TOF mass spectrometry [56]. Fragment spectra for fusaricidin A $(m / z=883.5)(\mathrm{A})$ and related compounds $(m / z=954.6(\mathrm{~B})$ and $899.6(\mathrm{C}))$ are shown in Figure $3 \mathrm{~A}-\mathrm{C}$.
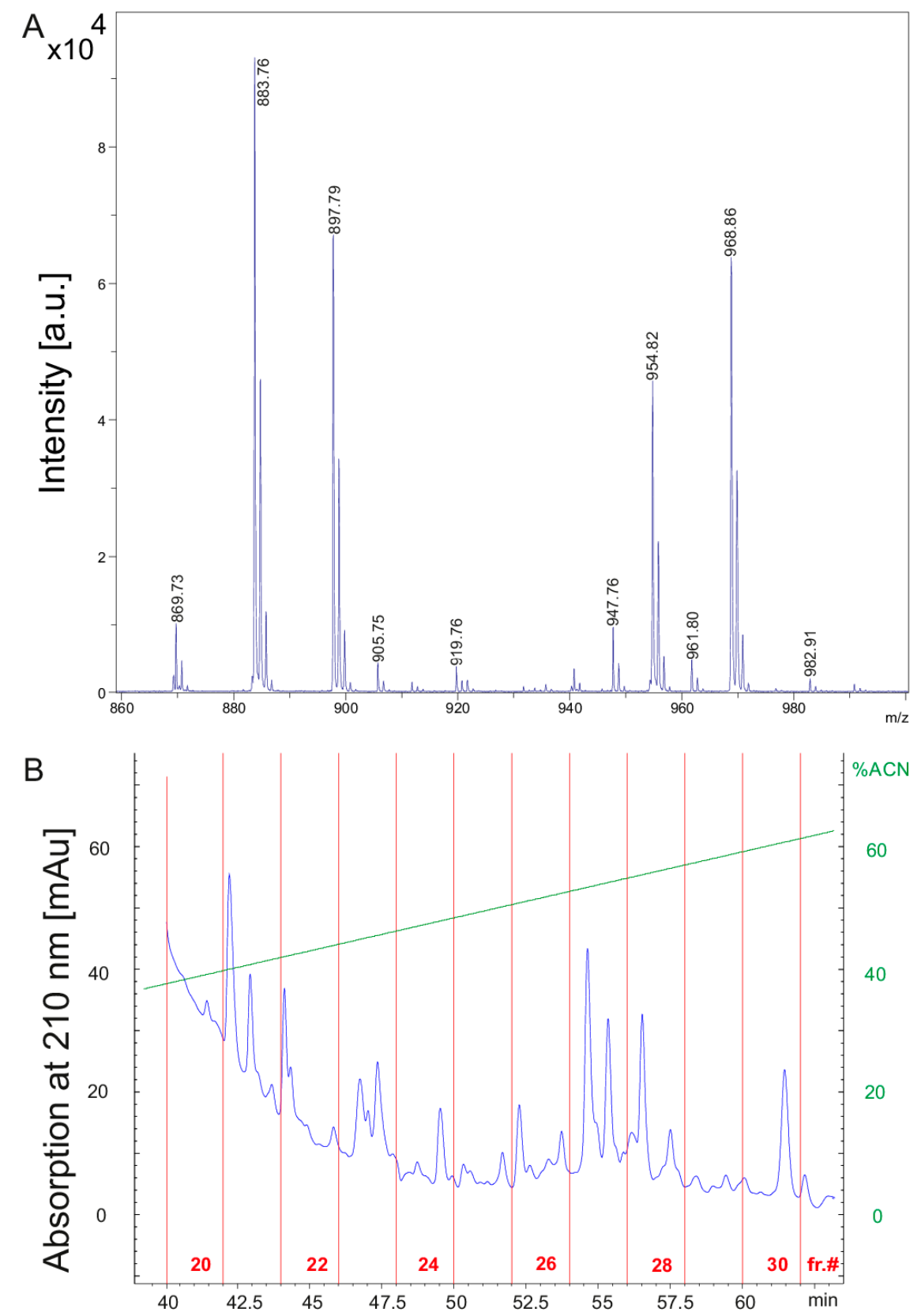

Figure 2. (A) MALDI-TOF mass spectrum of the culture filtrate of P. polymyxa DSM 32871 cultivated in the LOP medium for $48 \mathrm{~h}$ in the mass range of $m / z=800-1040$ covering the fusaricidin complex. (B) HPLC-chromatogram demonstrating fractionation of the culture filtrate of DSM 32871. The ordinate shows scales for the absorption at $210 \mathrm{~nm}$ in $\mathrm{mAU}$ and for the percentage of the eluent acetonitrile. The abscissa indicates the fraction number and the elution time. 
Table 1. Fusaricidins produced by P. polymyxa DSM 32871.

\begin{tabular}{|c|c|c|c|c|c|}
\hline & Fusaricidins $m / z$ & $m / z+71$ & Fragment a $\mathrm{m} / \mathrm{z}$ & Fragment $b \mathrm{~m} / \mathrm{z}$ & HPLC-Fraction \\
\hline \multirow{3}{*}{\multicolumn{2}{|c|}{855.51}} & & $256.10(\mathrm{C} 15)$ & 600.16 & 24 \\
\hline & & & 228.09 (C13) & 628.18 & \\
\hline & & 926.55 & 256.0 & 671.42 & 24 \\
\hline & 869.53 & & 256.15 (C15) & 614.12 & 25 \\
\hline & & & 228.18 (C13) & 642.21 & \\
\hline & & 940.57 & 256.09 & 685.15 & 24 \\
\hline $\mathrm{A}$ & 883.53 & & 256.25 & 628.32 & 26 \\
\hline $\mathrm{A}$ & & 954.57 & 256.21 & 699.21 & 25 \\
\hline $\mathrm{B}$ & 897.58 & & 256.29 & 642.38 & 27 \\
\hline $\mathrm{B}$ & & 968.62 & 256.19 & 713.22 & 25 \\
\hline $\mathrm{E}$ & 911.55 & & 256.26 & 656.16 & $27 / 28$ \\
\hline $\mathrm{E}$ & & 982.62 & 256.26 & 727.32 & 26 \\
\hline $\mathrm{F}$ & 925.58 & & 256.22 & 670.22 & $28 / 29$ \\
\hline $\mathrm{F}$ & & 996.65 & 256.20 & 741.34 & $27 / 28$ \\
\hline $\mathrm{C}$ & 947.51 & & 256.28 & 692.28 & 25 \\
\hline $\mathrm{C}$ & & 1018.58 & 256.21 & 763.19 & 25 \\
\hline $\mathrm{D}$ & 961.55 & & 256.20 & 706.23 & 25 \\
\hline \multirow[t]{2}{*}{$\mathrm{D}$} & & 1032.61 & 256.17 & 777.10 & 25 \\
\hline & $m / z+16$ & $m / z+71$ & & & \\
\hline $\mathrm{A}$ & 899.55 & & 272.18 & 628.27 & 22 \\
\hline $\mathrm{A}$ & & 970.51 & 272.13 & 699.22 & $22 / 23$ \\
\hline $\mathrm{B}$ & 913.57 & & 272.12 & 642.16 & $22 / 23$ \\
\hline B & & 984.52 & 272.15 & 713.25 & $22 / 23$ \\
\hline \multicolumn{6}{|c|}{$m / z+14$} \\
\hline & 897.25 & & 270.15 & 628.25 & 23 \\
\hline & 911.24 & & 270.10 & 642.16 & 23 \\
\hline
\end{tabular}

In previous studies $[10,11]$ we demonstrated that by laser excitation fusaricidins preferentially are decomposed in B-position to the carboxyl group of their fatty acid residue forming two characteristic fragments $a$ and $b$ according to the fragment pattern displayed in Scheme 1 for ring-opened fusaricidin A:

\section{Fusaricidin A}

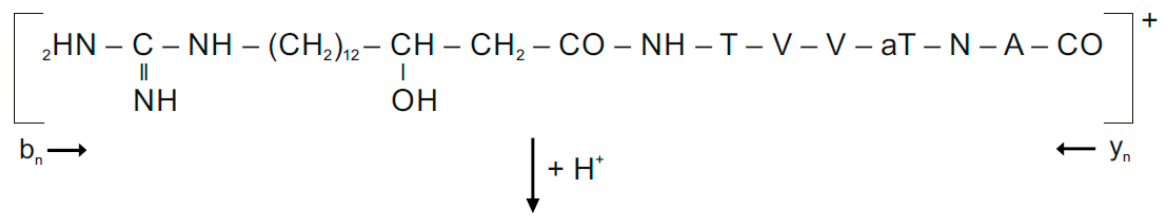

\section{Fragment a}<smiles>N=C(N)NCCCO</smiles>

\section{Fragment $b$}

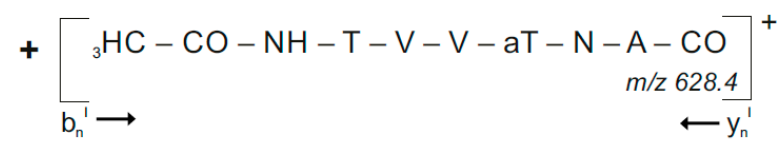

Scheme 1. Decomposition of fusaricidin A on laser excitation.

Fragment $a$ functions as an indicator for the fatty acid constituent of fusaricidins which is shortened by the two carbon atoms at its C-terminal end, which are connected via the carboxyl group of the fatty acid component with the amino group of the starter amino acid being part of fragment $b$ containing the complete peptide chain. In Figure 3 the mass peak of fragment $a$ was strongly dominating in the product ion spectra of fusaricidins, while fragment $b$ appeared with substantially lower intensity. Fragment $b$ was visualized in the expanded mass region from $m / z=600-720$. The molecular masses for the fusaricidins 
produced by P. polymyxa DSM 32871 together with the mass data for the corresponding fragment ions $a$ and $b$ derived from the product ion spectra are summarized in Table 1.
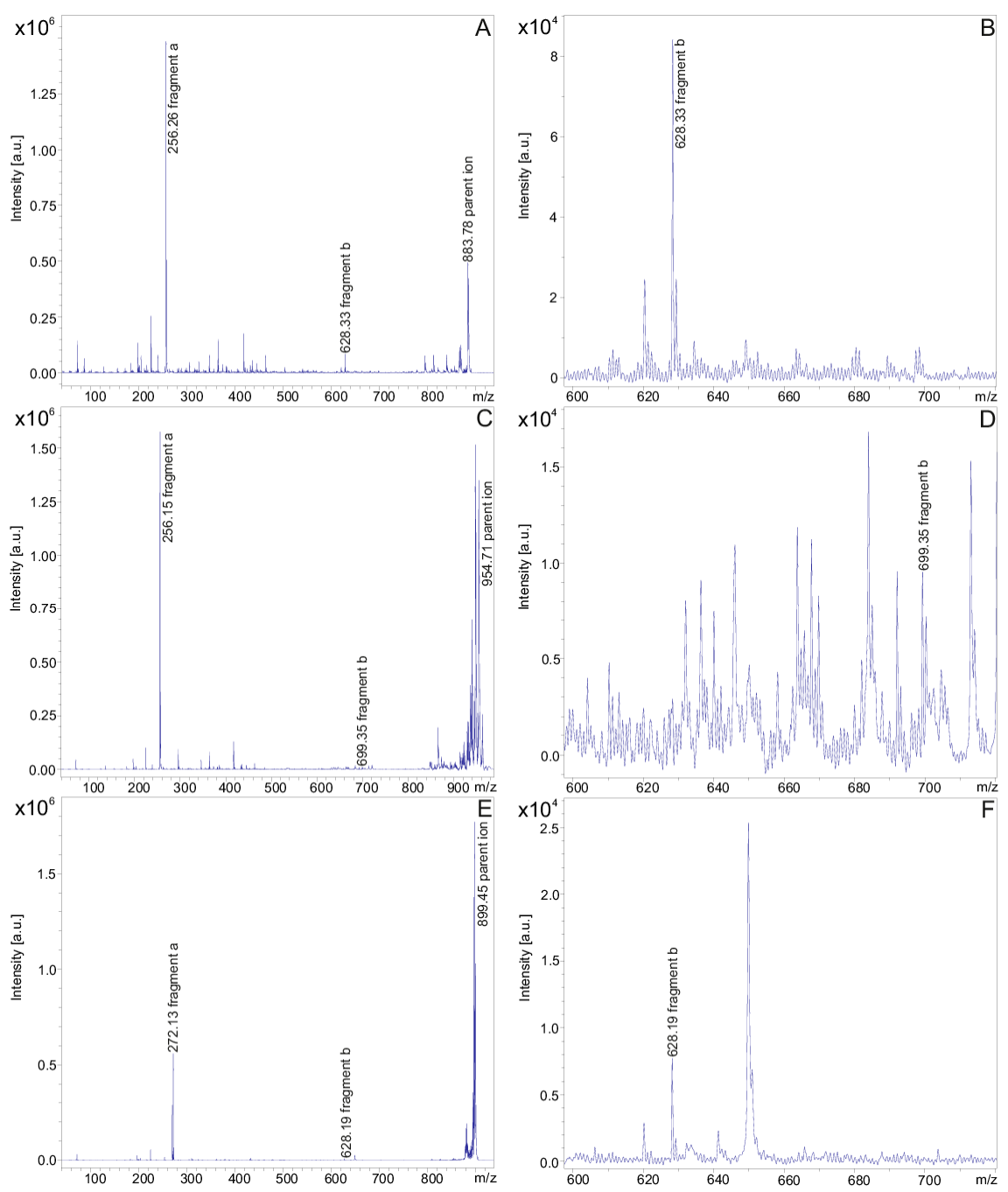

Figure 3. LIFT-MALDI-TOF/TOF product ion spectra of fusaricidin $\mathrm{A}\left([\mathrm{M}+\mathrm{H}]^{+}=883.74\right)(\mathbf{A}, \mathbf{B})$ and the novel derivatives of this compound with molecular masses $[\mathrm{M}+\mathrm{H}+71]^{+}=954.63(\mathbf{C}, \mathbf{D})$ and $[\mathrm{M}+\mathrm{H}+16]^{+}=899.43(\mathbf{E}, \mathbf{F})$, respectively. $(\mathbf{A}, \mathbf{C}, \mathbf{E})$ cover the complete product ion spectra exhibiting fragments $a$ and the parent ions. (B,D,F) present the expanded mass range from $m / z=600-720$ visualizing fragments $b$.

In Figure 3A,B the fragment spectrum of fusaricidin A with a C15-guanidino-pentadeca3-hydroxy fatty acid chain is shown. As is apparent from Scheme 1 [11] here the mass numbers of fragments $a$ and $b$ amount to $m / z=256.3$ and 628.3, respectively. For the +71derivative the same value for fragment $a$ was found as for the unsubstituted fusaricidin A (Figure 3C), but fragment $b$ as apparent in Figure 3D was 71 mass units higher $(m / z=699.2)$ indicating that the modification is located in the peptide portion. In contrast, for the +16 -variant of fusaricidin $\mathrm{A}(\mathrm{m} / \mathrm{z}=899.6)$ fragment $a \mathrm{~m} / \mathrm{z}=272.2$ (Figure 3E) was 16 mass units higher than for the unsubstituted fusaricidin A, while the peptide part $(\mathrm{m} / \mathrm{z}=628.3$ for fragment $b$ ) remained unchanged (Figure 3F). Apparently, here the fatty acid part of the derivative is hydroxylated.

By evaluation of the LIFT-TOF/TOF product ion spectra of the fusaricidins produced by DSM 32871 listed in Table 1, a third group of yet unknown variants was found with molecular masses $m / z=897.3$ and 911.2, which revealed as derivatives of fusaricidins $\mathrm{A}$ and $\mathrm{B}$, exhibiting a value of $m / z=270.3$ for fragment $a$. According to the data for 
fragment $b$ of $m / z=628.3$ and 642.2 they can be attributed to fusaricidins A and B bearing a C16-guanidino-3-hydroxy-hexadecameric acid as fatty acid constituent.

In Figure $4 \mathrm{~A}-\mathrm{C}$ the complete sequence of fusaricidin $\mathrm{A}$ and its +71 - and +16-variants obtained from series of $b_{n}$ - and $y_{n}$-fragment ions are demonstrated. Indeed, unsubstituted fusaricidin A (Figure 3A) and its +16-derivative (Figure 3C) show the same peptide sequence, while the +71 -variant (Figure $3 \mathrm{~B}$ ) is substituted at its allo-threonine residue in position 4 by an alanine forming an ester bond with its free hydroxyl group. This feature is corroborated by the sequence of the corresponding fragments $b$ of fusaricidin A (Figure 5A) and its +71 -derivative (Figure $5 \mathrm{~B}$ ). These results were substantiated by the product ion spectra in Supplementary Materials (Figure S3A,B) showing their upper part in expanded version. Here, the value of fragment $b_{4}(m / z=769.14)$ is 71 mass units higher than $b_{4}$ of the unmodified fusaricidin $\mathrm{A}$, indicating substitution of allo-Thr in position 4 by an alanine. Correspondingly, $\mathrm{b}_{5}(m / z=812.63)$ is shifted to $m / z 883.66$ in the case of the +71 -variant with a molecular mass of $m / z=954.6$. This result is compatible with previous data obtained for fusaricidins C and D [10].

\begin{tabular}{|c|c|c|c|c|c|c|c|c|}
\hline $\mathrm{b}_{\mathrm{n}}$ found & $\left.\left[\mathrm{M}+\mathrm{H}-\mathrm{H}_{2} \mathrm{O}\right]-\mathrm{NH}_{3}\right]^{+}$ & 263.22 & 364.27 & 463.32 & 562.36 & 663.46 & 777.58 & 848.82 \\
\hline $\mathrm{b}_{\mathrm{n}}$ found & {$\left[\mathrm{M}+\mathrm{H}-\mathrm{H}_{2} \mathrm{O}\right]^{+}$} & 280.24 & 381.28 & - & 579.18 & 680.49 & 794.60 & 865.66 \\
\hline $\mathrm{b}_{\mathrm{n}}$ found & {$[\mathrm{M}+\mathrm{H}]^{+}$} & 298.23 & - & - & - & 698.51 & 812.63 & 883.74 \\
\hline \multirow[t]{2}{*}{$b_{n}$ calc. } & {$[\mathrm{M}+\mathrm{H}]^{+}$} & 298.26 & 399.31 & 498.37 & 597.44 & 698.49 & 812.53 & 883.57 \\
\hline & & GHPD & $\begin{array}{l}\text { Thr } \\
\text { (1) }\end{array}$ & $\begin{array}{l}\text { Val } \\
\text { (2) }\end{array}$ & $\begin{array}{l}\text { Val } \\
\text { (3) }\end{array}$ & $\begin{array}{l}\text { a-Thr } \\
\text { (4) }\end{array}$ & $\begin{array}{c}\text { Asn } \\
(5)\end{array}$ & $\begin{array}{c}\text { Ala } \\
(6)\end{array}$ \\
\hline $\mathrm{y}_{\mathrm{n}}$ calc. & {$[\mathrm{M}+\mathrm{H}]^{+}$} & 883.57 & 586.32 & 485.27 & 386.20 & 287.13 & 186.08 & 72.04 \\
\hline$y_{n}$ found & {$[\mathrm{M}+\mathrm{H}]^{+}$} & 883.74 & - & 485.24 & 386.20 & 287.14 & 186.11 & 72.10 \\
\hline \multirow{5}{*}{$\begin{array}{l}b_{n} \text { found } \\
b_{n} \text { found } \\
b_{n} \text { found } \\
b_{n} \text { calc. }\end{array}$} & $\left.\left[\mathrm{M}+\mathrm{H}-\mathrm{H}_{2} \mathrm{O}\right]-\mathrm{NH}_{3}\right]^{+}$ & 263.22 & 364.27 & 463.30 & - & - & 848.74 & - \\
\hline & {$\left[\mathrm{M}+\mathrm{H}-\mathrm{H}_{2} \mathrm{O}\right]^{+}$} & 280.24 & 381.28 & - & 579.18 & - & 865.64 & 936.74 \\
\hline & {$[\mathrm{M}+\mathrm{H}]^{+}$} & 298.23 & - & - & 597.23 & 769.14 & 883.66 & 954.78 \\
\hline & {$[\mathrm{M}+\mathrm{H}]^{+}$} & 298.26 & 399.31 & 498.37 & 597.44 & 769.53 & 883.57 & 954.61 \\
\hline & & GHPD & Thr & Val & Val & & Asn & Ala \\
\hline $\mathrm{y}_{\mathrm{n}}$ calc. & {$[\mathrm{M}+\mathrm{H}]^{+}$} & 954.61 & 657.36 & 556.31 & 457.24 & 358.17 & 186.08 & 72.04 \\
\hline$y_{n}$ found & {$[\mathrm{M}+\mathrm{H}]^{+}$} & 954.78 & - & - & - & 358.18 & 186.11 & 72.10 \\
\hline $\mathrm{b}_{\mathrm{n}}$ found & $\left.\left[\mathrm{M}+\mathrm{H}-\mathrm{H}_{2} \mathrm{O}\right]-\mathrm{NH}_{3}\right]^{+}$ & - & 380.23 & 479.30 & 578.35 & - & 793.45 & 864.52 \\
\hline $\mathrm{b}_{\mathrm{n}}$ found & {$\left[\mathrm{M}+\mathrm{H}-\mathrm{H}_{2} \mathrm{O}\right]^{+}$} & 296.19 & 397.25 & - & - & - & 810.48 & 881.43 \\
\hline$b_{n}$ found & {$[\mathrm{M}+\mathrm{H}]^{+}$} & - & 415.29 & 514.30 & - & - & 828.50 & 899.43 \\
\hline $\mathrm{b}_{\mathrm{n}}$ calc. & {$[\mathrm{M}+\mathrm{H}]^{+}$} & 314.24 & 415.29 & 514.36 & 613.43 & 714.48 & 828.52 & 899.56 \\
\hline & Or & -GHPD & Thr & Val & Val & a-Thr & Asn & Ala \\
\hline $\mathrm{y}_{\mathrm{n}}$ calc. & {$[\mathrm{M}+\mathrm{H}]^{+}$} & 899.56 & 586.32 & 485.27 & 386.20 & 287.13 & 186.08 & 72.04 \\
\hline $\mathrm{Y}_{\mathrm{n}}$ found & {$[\mathrm{M}+\mathrm{H}]^{+}$} & 899.43 & 586.25 & - & 386.19 & 287.10 & 186.03 & 72.03 \\
\hline
\end{tabular}

Figure 4. Sequence of fusaricidin A (precursor ion $\left.[\mathrm{M}+\mathrm{H}]^{+}=883.74\right)(\mathrm{A})$ and its derivatives modified at the hydroxyl group of D-allo-Thr in position 4 by alanine (precursor ion $[\mathrm{M}+\mathrm{H}+71]^{+}=954.78$ ) (B) and by an additional hydroxyl group in its GDPH fatty acid side chain (precursor ion $\left.[\mathrm{M}+\mathrm{H}+16]^{+}=899.43\right)(\mathrm{C})$ derived from their LIFT-TOF/TOF product ion spectra. Structural analysis was based on three sets of $b_{n}$-fragment ions, obtained either in their intact form or after elimination of $\mathrm{H}_{2} \mathrm{O}\left(\mathrm{b}_{\mathrm{n}}\left(-\mathrm{H}_{2} \mathrm{O}\right)\right)$ as well as of both $\mathrm{H}_{2} \mathrm{O}$ and $\mathrm{NH}_{3}\left(\mathrm{~b}_{\mathrm{n}}\left(-\mathrm{H}_{2} \mathrm{O} ;-\mathrm{NH}_{3}\right)\right)$, respectively. They were corroborated by the corresponding series of $\mathrm{y}_{\mathrm{n}}$-ions. 


\begin{tabular}{|c|c|c|c|c|c|c|c|c|}
\hline \multirow{4}{*}{$\begin{array}{l}b_{n} \text { found } \\
b_{n} \text { found }\end{array}$} & {$\left[\mathrm{M}+\mathrm{H}-\mathrm{H}_{2} \mathrm{O}\right]^{+}$} & - & 126.07 & 225.13 & 324.18 & 425.21 & 539.27 & 610.32 \\
\hline & {$[\mathrm{M}+\mathrm{H}]^{+}$} & 42.92 & 144.07 & - & - & - & - & 628.32 \\
\hline & {$[\mathrm{M}+\mathrm{H}]^{+}$} & 43.02 & 144.07 & 243.14 & 342.21 & 443.26 & 557.30 & 628.34 \\
\hline & & $\mathrm{CH}_{3}-\mathrm{CO}$ & $\begin{array}{l}\text { Thr } \\
\text { (1) }\end{array}$ & $\begin{array}{l}\text { Val } \\
\text { (2) }\end{array}$ & $\begin{array}{l}\text { Val } \\
\text { (3) }\end{array}$ & $\begin{array}{c}\text { a-Thr } \\
\text { (4) }\end{array}$ & $\begin{array}{l}\text { Asn } \\
\text { (5) }\end{array}$ & $\begin{array}{c}\text { Ala } \\
\text { (6) }\end{array}$ \\
\hline $\mathrm{y}_{\mathrm{n}}$ calc. & {$[\mathrm{M}+\mathrm{H}]^{+}$} & 628.34 & 586.32 & 485.27 & 386.20 & 287.13 & 186.08 & 72.04 \\
\hline$y_{n}$ found & {$[\mathrm{M}+\mathrm{H}]^{+}$} & 628.32 & - & 485.24 & 386.20 & 287.14 & 186.11 & 72.10 \\
\hline
\end{tabular}

\begin{tabular}{|c|c|c|c|c|c|c|c|c|}
\hline$b_{n}$ found & {$\left[\mathrm{M}+\mathrm{H}-\mathrm{H}_{2} \mathrm{O}\right]^{+}$} & - & 126.07 & 225.13 & 324.18 & - & 610.18 & - \\
\hline$b_{n}$ found & {$[\mathrm{M}+\mathrm{H}]^{+}$} & 42.98 & 144.08 & - & - & - & 628.31 & 699.26 \\
\hline$b_{n}$ calc. & {$[\mathrm{M}+\mathrm{H}]^{+}$} & 43.02 & 144.07 & 243.14 & 342.21 & 514.30 & 628.34 & 699.38 \\
\hline & & $\mathrm{CH}_{3}-\mathrm{CO}$ & Thr & Val & Val & $\stackrel{\text { Ala }}{\downarrow}$ & Asn & Ala \\
\hline $\mathrm{y}_{\mathrm{n}}$ calc. & {$[\mathrm{M}+\mathrm{H}]^{+}$} & 699.38 & 657.35 & 556.30 & 457.24 & 358.17 & 186.08 & 72.04 \\
\hline $\mathrm{y}_{\mathrm{n}}$ found & {$[\mathrm{M}+\mathrm{H}]^{+}$} & 699.26 & - & - & - & 358.13 & 186.08 & 72.07 \\
\hline
\end{tabular}

Figure 5. Sequence of fragments $b$ of fusaricidin A (A) and its derivative modified at the hydroxyl group of D-allo-Thr in position 4 by alanine (B) determined by LIFT-TOF/TOF mass spectrometry.

In Figure 6 and Table 2 the polymyxin products of the two investigated P. polymyxa strains are shown. DSM 32871 produces two isomers of polymyxin E (E1 and E2) with molecular masses $[\mathrm{M}+\mathrm{H}]^{+}=1155.7$ and 1169.8 (see Table 2), while M1 forms two variants of polymyxin $\mathrm{P}\left(\mathrm{P} 1\right.$ and $\mathrm{P} 2$ ) with masses of $[\mathrm{M}+\mathrm{H}]^{+}=1177.4$ and 1191.4 (Figure $6 \mathrm{C}$ and Table 2) $[38,44]$. For both strains the isomers differ by a C8 or a C9 fatty acid. The protonated forms of these polymyxin families together with their alkali adducts are summarized in Figure 6 and Table 2. Both polymyxins have a high affinity for potassium, as shown by the $[\mathrm{M}-\mathrm{H}+2 \mathrm{~K}]^{+}$-ions indicating binding of two potassium atoms.

Table 2. Polymyxins produced by P. polymyxa strains DSM 32871 and M1.

\begin{tabular}{ccc}
\hline & Strain DSM 32871: Polymyxin E & Strain M1: Polymyxin P \\
\hline$[\mathrm{M}+\mathrm{H}, \mathrm{Na}, \mathrm{K}]^{+}$ & E1: $1155.7 / 1177.8 / 1193.8$ & P1: $1177.4 / 1199.3 / 1215.4$ \\
& E2: $1169.8 / 1191.8 / 1207.8$ & P2: 1191.4/1213.4/1229.3 \\
\hline$[\mathrm{M}-\mathrm{H}+2 \mathrm{~K}]^{+}$ & E1: 1231.9 & P1: 1253.9 \\
& E2: 1245.9 & P2: 1267.9 \\
\hline$[\mathrm{M}+\mathrm{H}+146]^{+}$ & E1: 1302.0 & P1: 1323.9 \\
& E2: 1316.0 & P2: 1337.9 \\
\hline \multirow{2}{*}[\mathrm{M}+\mathrm{H}+197]{$^{+}$} & E1: 1352.9 & \\
\hline
\end{tabular}

The structure of polymyxins E studied by LIFT-MALDI-TOF/TOF MS is presented in Figure 7. Product ion spectra were taken either starting from the fatty acid constituent or the first amino acid Dab (1) (Figure 7A) as well as from Dab (5) and Leu (6) (Figure 7B) modelling the polymyxin structure from series of $b_{n}-$ and $y_{n}$-ions. The fatty acid residues show masses of $m / z=126.1$ and 140.1 , respectively. The obtained sequence of polymyxin $\mathrm{E}$ is in accordance with the data reported in the literature [38-42]. The structure of polymyxin $P$ was presented in a previous paper $[36,44]$. 

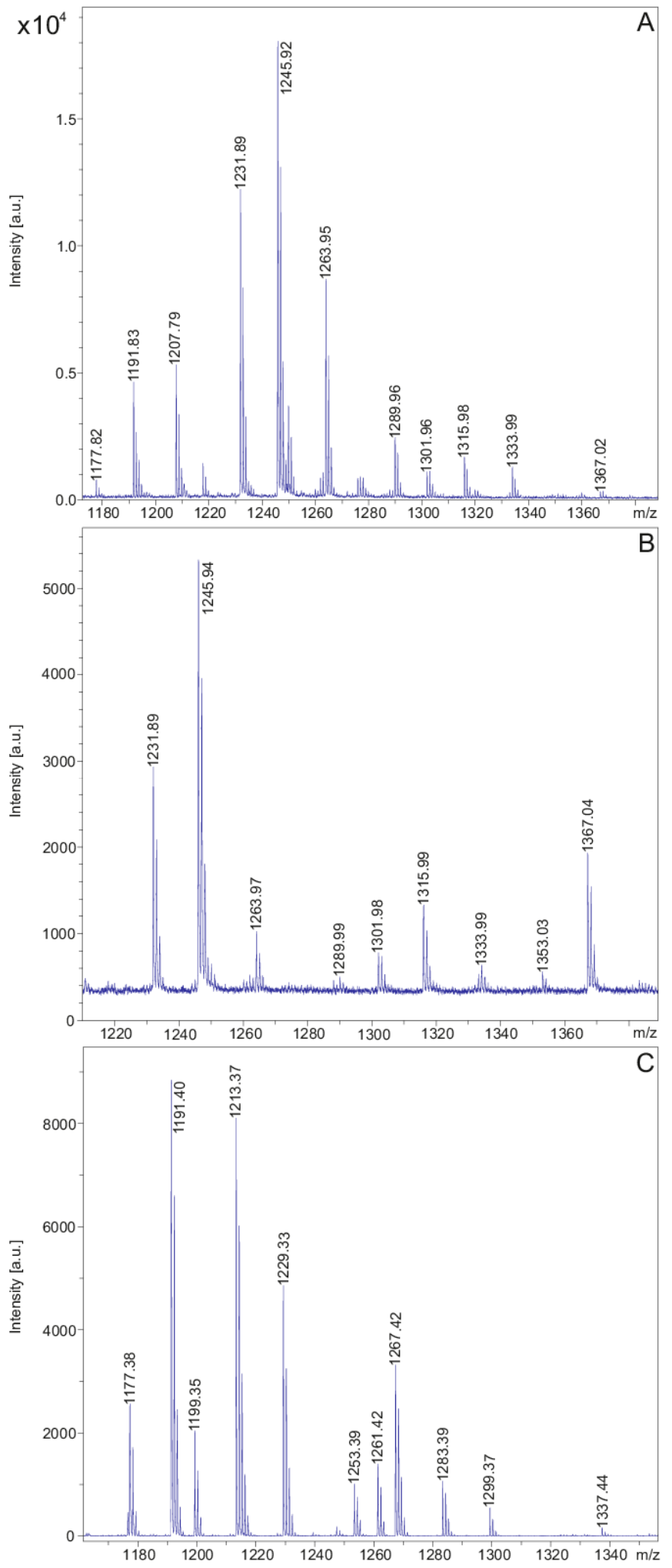

Figure 6. MALDI-TOF mass spectra of the polymyxin families produced by P. polymyxa DSM 32871 $(\mathbf{A}, \mathbf{B})$ and M1 (C) detected in the culture filtrates of these strains which were grown in the LOP medium for $48 \mathrm{~h}$. Spectrum A was recorded in the mass range $m / z=1180-1380$ and shown in expanded form from $m / z=1210-1380$ in B. 


\begin{tabular}{|c|c|c|c|c|c|c|c|c|c|c|c|c|}
\hline \multirow{3}{*}{$\begin{array}{l}b_{n} \text { found } \\
b_{n} \text { found } \\
b_{n} \text { calc. }\end{array}$} & \multicolumn{2}{|c|}{$\left[\mathrm{M}+\mathrm{H}-\mathrm{H}_{2} \mathrm{O}\right]^{+}$} & - & 184.04 & 284.15 & - & - & - & 710.21 & 10.10 & - & - \\
\hline & \multicolumn{2}{|l|}{$[\mathrm{M}+\mathrm{H}]^{+}$} & 101.01 & 202.04 & 302.15 & 402.14 & - & - & 728.24 & 828.23 & 928.75 & 1029.20 \\
\hline & \multicolumn{2}{|l|}{$[\mathrm{M}+\mathrm{H}]^{+}$} & 101.07 & 202.12 & 302.18 & 402.25 & 502.31 & 615.39 & 728.48 & 828.54 & 928.60 & 1029.65 \\
\hline $\mathrm{b}_{\mathrm{n}}$ found & \multicolumn{2}{|c|}{$\left[\mathrm{M}+\mathrm{H}-\mathrm{H}_{2} \mathrm{O}\right]^{+}-$} & - & 324.11 & 424.19 & 524.21 & - & - & 850.37 & 950.55 & 1050.91 & 1151.64 \\
\hline $\mathrm{b}_{\mathrm{n}}$ found & {$[\mathrm{M}+\mathrm{H}]^{+}$} & 140.95 & 241.03 & 342.12 & 442.21 & - & - & - & - & - & 1068.88 & 1169.70 \\
\hline \multirow[t]{2}{*}{$b_{n}$ calc. } & {$[\mathrm{M}+\mathrm{H}]^{+}$} & 141.13 & 241.19 & 342.24 & 442.30 & 542.37 & 642.43 & 755.51 & 868.60 & 968.66 & 1068.72 & 1169.77 \\
\hline & & FA & $\begin{array}{c}\text { Dab } \\
\text { (1) }\end{array}$ & $\begin{array}{c}\text { Thr } \\
\text { (2) }\end{array}$ & $\begin{array}{c}\text { Dab } \\
\text { (3) }\end{array}$ & $\begin{array}{c}\text { Dab } \\
(4)\end{array}$ & $\begin{array}{c}\text { Dab } \\
(5)\end{array}$ & $\begin{array}{c}\text { Leu } \\
(6)\end{array}$ & $\begin{array}{c}\text { Leu } \\
\text { (7) }\end{array}$ & $\begin{array}{c}\text { Dab } \\
(8)\end{array}$ & $\begin{array}{c}\text { Dab } \\
\text { (9) }\end{array}$ & $\begin{array}{l}\text { Thr } \\
\text { (10) }\end{array}$ \\
\hline $\mathrm{y}_{\mathrm{n}}$ calc. & {$[(V)+\pi]$} & 7 & 102 & 929.59 & 4 & 728.48 & 6 & 35 & 27 & 18 & 12 & 102.06 \\
\hline$y_{n}$ found & {$[\mathrm{M}+\mathrm{H}]^{+}$} & 1169.70 & 1029.20 & 929.17 & 828.23 & 728.24 & 628.23 & 528.20 & 415.24 & 302.15 & 202.04 & - \\
\hline$y_{n}$ found & {$\left[\mathrm{M}+\mathrm{H}-\mathrm{H}_{2} \mathrm{O}\right]$} & 1151.64 & - & 911.21 & 810.10 & 710.21 & 610.22 & 510.22 & 397.25 & 284.15 & 184.04 & - \\
\hline
\end{tabular}

\begin{tabular}{|c|c|c|c|c|c|c|c|c|c|c|c|}
\hline \multirow{3}{*}{$\begin{array}{l}b_{n} \text { found } \\
b_{n} \text { found } \\
b_{n} \text { calc. }\end{array}$} & \multicolumn{2}{|c|}{$\left[\mathrm{M}+\mathrm{H}-\mathrm{H}_{2} \mathrm{O}\right]^{+}$} & - & 209.00 & 309.10 & 409.15 & 510.12 & 610.09 & 710.10 & 811.00 & 911.04 \\
\hline & \multicolumn{2}{|l|}{$[\mathrm{M}+\mathrm{H}]^{+}$} & - & 227.03 & 327.12 & 427.18 & 528.13 & 628.12 & 728.12 & - & 929.26 \\
\hline & \multicolumn{2}{|l|}{$[\mathrm{M}+\mathrm{H}]^{+}$} & 114.09 & 227.18 & 327.24 & 427.30 & 528.35 & 628.41 & 728.48 & 829.53 & 929.59 \\
\hline \multirow{4}{*}{$\begin{array}{l}\mathrm{b}_{\mathrm{n}} \text { found } \\
\mathrm{b}_{\mathrm{n}} \text { found } \\
\mathrm{b}_{\mathrm{n}} \text { calc. }\end{array}$} & \multicolumn{2}{|c|}{$\left[\mathrm{M}+\mathrm{H}-\mathrm{H}_{2} \mathrm{O}\right]^{+}$} & 196.00 & 309.10 & 409.15 & 509.12 & 610.09 & 710.10 & - & 911.04 & 1011.35 \\
\hline & {$[\mathrm{M}+\mathrm{H}]^{+}$} & 101.00 & 214.02 & 327.12 & 427.18 & - & 628.12 & 728.12 & - & 929.26 & 1029.72 \\
\hline & {$[\mathrm{M}+\mathrm{H}]^{+}$} & 101.07 & 214.16 & 327.24 & 427.30 & 527.37 & 628.41 & 728.48 & 828.54 & 929.59 & 1029.65 \\
\hline & & $\begin{array}{c}\text { Dab } \\
(5)\end{array}$ & $\begin{array}{l}\text { Leu } \\
\text { (6) }\end{array}$ & $\begin{array}{l}\text { Leu } \\
\text { (7) }\end{array}$ & $\begin{array}{c}\text { Dab } \\
\text { (8) }\end{array}$ & $\begin{array}{c}\text { Dab } \\
\text { (9) }\end{array}$ & $\begin{array}{l}\text { Thr } \\
(10)\end{array}$ & $\begin{array}{c}\text { Dab } \\
(4)\end{array}$ & $\begin{array}{c}\text { Dab } \\
\text { (3) }\end{array}$ & $\begin{array}{l}\text { Thr } \\
\text { (2) }\end{array}$ & $\begin{array}{c}\text { Dab } \\
\text { (1) }\end{array}$ \\
\hline $\mathrm{y}_{\mathrm{n}}$ calc. & {$[\mathrm{M}+\mathrm{H}]^{+}$} & 1029.65 & 929.59 & 816.50 & 703.42 & 603.36 & 503.29 & 402.25 & 302.18 & 202.12 & 101.07 \\
\hline$y_{n}$ found & {$[\mathrm{M}+\mathrm{H}]^{+}$} & 1029.72 & 929.26 & 816.08 & - & 603.05 & 503.10 & 402.13 & 302.08 & 201.97 & 101.00 \\
\hline $\mathrm{y}_{\mathrm{n}}$ found [ & $\left.\mathrm{M}+\mathrm{H}-\mathrm{H}_{2} \mathrm{O}\right]^{+}$ & +1011.35 & 911.04 & - & - & - & 485.12 & - & 284.05 & 183.96 & - \\
\hline
\end{tabular}

Figure 7. Sequence of the sodium adduct of polymyxin E2 (precursor ion $[\mathrm{M}+\mathrm{Na}]^{+}=1191.8$ ) derived from LIFT-MALDITOF/TOF product ion spectra which were taken either starting from the fatty acid constituent or the first amino acid Dab (1) (A) as well as from Dab (5) and Leu (6) (B) modelling the polymyxin structure from series of $b_{n}$ - and $y_{n}$-ions.

Interestingly, both for polymyxin $\mathrm{E}$ and $\mathrm{P}$ we observed a family of minor species apparent from Figure 6 at the higher mass range. For example, mass peaks were found at $m / z=1302.0$ and 1316.0 for polymyxin $\mathrm{E}$ as well as at $m / z=1323.9$ and 1337.9 for polymyxin $\mathrm{P}$ each showing a mass difference of approximately $146 \mathrm{Da}$ relating to the protonated unsubstituted forms of E1/E2 and P1/P2, respectively (see Table 2). These species were sequenced by LIFT-MALDI-TOF/TOF MS. All of them showed the polymyxin sequence with a substitution of the Dab residue in position 4 by a threonine in combination with yet unknown structural elements at the C-terminal end of approx. 146 or $197 \mathrm{Da}$. This replacement was corroborated by nearest neighbor studies in Table 3 modelling the polymyxin structure by di-, tri-, tetra- and pentapeptide analysis.

For example, in Figure 8 sequencing of the species with a molecular mass of $m / z=1316.0$ is demonstrated which is a derivative of polymyxin E2 modified at its C-terminal end with a residue of approximately $146 \mathrm{Da}$. Similar results were achieved for the corresponding E1 derivative with a molecular mass of $m / z=1302$.0. These compounds show a higher hydrophobicity than the original polymyxins demonstrated in Figures 6 and 7. In the HPLCprofile (Figure 2B) they were found in fractions 28 and 29 together with the tridecaptins, while the unsubstituted polymyxins $\mathrm{E}$ appeared in fraction 23 . The nature of the additional elements in the sequence of the minor species have still to be elucidated. 


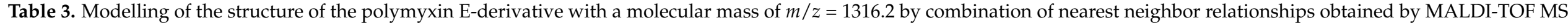

(a) Dipeptide Fragments

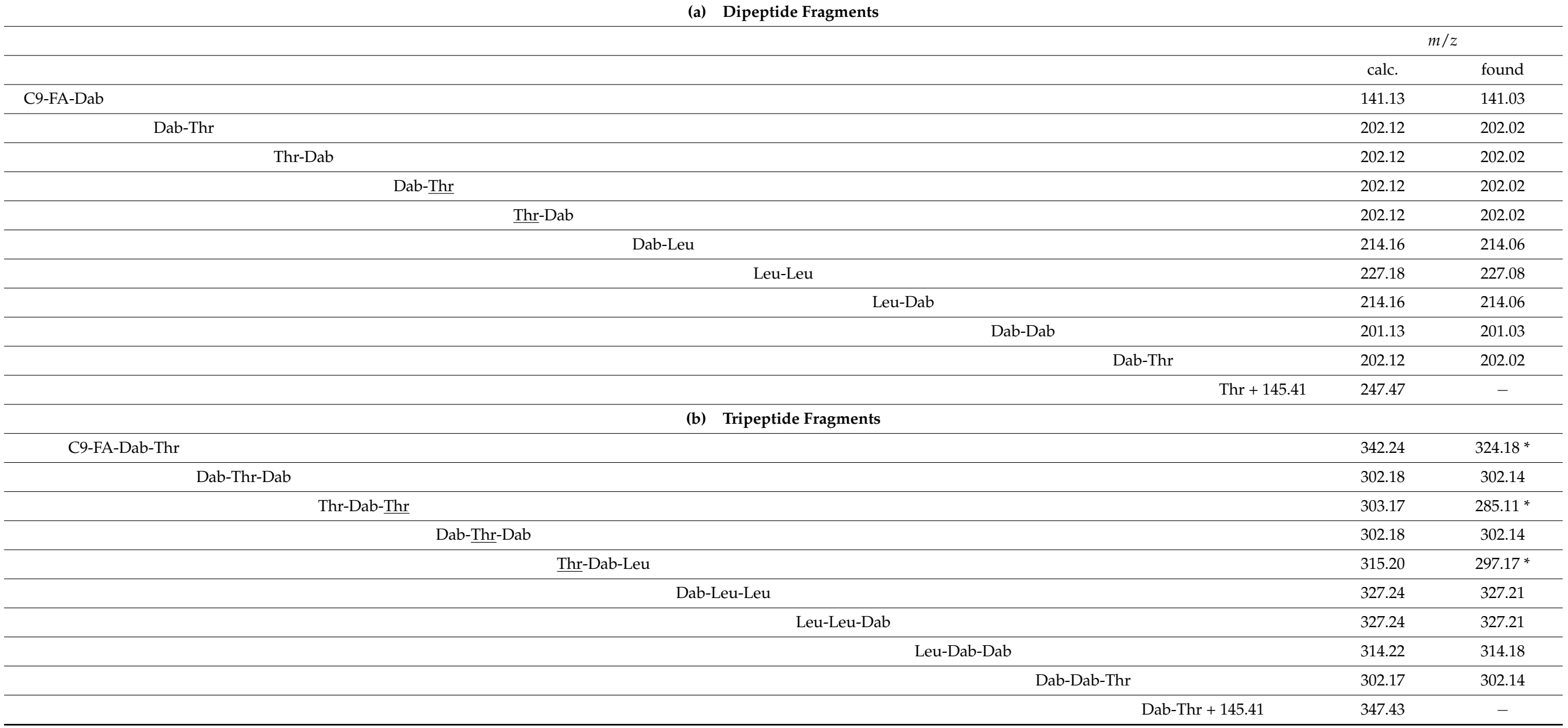


Table 3. Cont.

(c) Tetrapeptide Fragments

\begin{tabular}{|c|c|c|}
\hline C9-FA-Dab-Thr-Dab & 442.30 & 442.20 \\
\hline Dab-Thr-Dab-Thr & 403.23 & 403.23 \\
\hline Thr-Dab-Thr-Dab & 403.23 & 403.23 \\
\hline Dab-Thr-Dab-Leu & 415.27 & 415.25 \\
\hline$\underline{\text { Thr-Dab_Leu-Leu }}$ & 428.29 & 410.28 * \\
\hline Dab-Leu-Leu-Dab & 427.30 & 427.26 \\
\hline Leu-Leu-Dab-Dab & 427.30 & 427.26 \\
\hline Leu-Dab-Dab-Thr & 415.27 & 415.25 \\
\hline Dab-Dab-Thr + 145.41 & 442.59 & 447.31 \\
\hline \multicolumn{3}{|l|}{ (d) Pentapeptide Fragments } \\
\hline C9-FA-Dab-Thr-Dab-Thr & 543.35 & $507.28 * *$ \\
\hline Dab-Thr-Dab-Thr-Dab & 503.35 & 503.25 \\
\hline Thr-Dab-Thr-Dab-Leu & 516.31 & $498.25 *$ \\
\hline Dab-Thr-Dab-Leu-Leu & 528.35 & 528.35 \\
\hline$\underline{\text { Thr-Dab-Leu-Leu-Dab }}$ & 528.35 & 528.35 \\
\hline Dab-Leu-Leu-Dab-Dab & 527.37 & - \\
\hline Leu-Leu.Dab-Dab-Thr & 528.35 & 528.35 \\
\hline Leu-Dab-Dab-Thr + 145.41 & 560.68 & - \\
\hline
\end{tabular}

Thr in position 4 is underlined. ${ }^{*}$ means $\left[\mathrm{M}+\mathrm{H}-\mathrm{H}_{2} \mathrm{O}\right]^{+} .{ }^{* *}$ means $\left[\mathrm{M}+\mathrm{H}-2 \mathrm{H}_{2} \mathrm{O}\right]^{+}$. 


\begin{tabular}{|c|c|c|c|c|c|c|c|c|c|c|c|c|c|}
\hline $\mathrm{b}_{\mathrm{n}}$ found & {$\left[\mathrm{M}+\mathrm{H}-\mathrm{H}_{2} \mathrm{O}\right]$} & & - & 184.01 & 284.13 & 385.23 & 485.25 & 598.26 & 711.30 & 811.27 & - & 1012.38 & - \\
\hline $\mathrm{b}_{\mathrm{n}}$ found & {$[\mathrm{M}+\mathrm{H}]^{+}$} & & 101.00 & 202.02 & 302.14 & 403.23 & 503.24 & - & - & - & - & 1030.64 & 1176.52 \\
\hline $\mathrm{b}_{\mathrm{n}}$ calc. & {$[\mathrm{M}+\mathrm{H}]^{+}$} & & 101.07 & 202.12 & 302.18 & 403.23 & 503.29 & 616.38 & 729.46 & 829.53 & 929.59 & 1030.64 & \\
\hline $\mathrm{b}_{\mathrm{n}}$ found & {$\left[\mathrm{M}+\mathrm{H}-\mathrm{H}_{2} \mathrm{O}\right]$} & ]$^{+}$ & 223.07 & 324.18 & 424.27 & - & - & 738.28 & - & 951.29 & - & 1152.55 & - \\
\hline $\mathrm{b}_{\mathrm{n}}$ found & {$[\mathrm{M}+\mathrm{H}]^{+}$} & 141.00 & 241.09 & 342.20 & 442.20 & - & - & - & - & - & - & 1170.24 & 1316.16 \\
\hline$b_{n}$ calc. & {$[\mathrm{M}+\mathrm{H}]^{+}$} & 141.13 & 241.19 & 342.24 & 442.30 & 543.35 & 643.41 & 756.50 & 869.58 & 969.64 & 1069.71 & 1170.75 & 1316.00 \\
\hline & & FA & $\begin{array}{c}\text { Dab } \\
\text { (1) }\end{array}$ & $\begin{array}{c}\text { Thr } \\
\text { (2) }\end{array}$ & $\begin{array}{c}\text { Dab } \\
\text { (3) }\end{array}$ & $\begin{array}{c}\text { Thr } \\
\text { (4) }\end{array}$ & $\begin{array}{c}\text { Dab } \\
\text { (5) }\end{array}$ & $\begin{array}{c}\text { Leu } \\
\text { (6) }\end{array}$ & $\begin{array}{c}\text { Leu } \\
\text { (7) }\end{array}$ & $\begin{array}{c}\text { Dab } \\
\text { (8) }\end{array}$ & $\begin{array}{c}\text { Dab } \\
(9)\end{array}$ & $\begin{array}{l}\text { Thr } \\
(10)\end{array}$ & ? \\
\hline$y_{n}$ calc. & {$[\mathrm{M}+\mathrm{H}]^{+}$} & & 1030.64 & 930.57 & 829.53 & 729.46 & 628.41 & 528.35 & 415.27 & 302.18 & 202.12 & 102.06 & \\
\hline$y_{n}$ found & {$[\mathrm{M}+\mathrm{H}]^{+}$} & & 1030.64 & - & - & - & - & 528.35 & 415.25 & 302.14 & 202.02 & 102.00 & \\
\hline$y_{n}$ found & {$\left[\mathrm{M}+\mathrm{H}-\mathrm{H}_{2} \mathrm{O}\right]$} & & 1012.38 & - & 811.27 & 711.30 & - & 510.32 & 397.23 & 284.13 & 184.01 & - & \\
\hline
\end{tabular}

Figure 8. Sequence determination of the modified derivative of polymyxin E1 (precursor ion $[\mathrm{M}+\mathrm{H}]^{+}=1316.16$ ) by LIFT-MALDI-TOF/TOF mass spectrometry.

Plant growth promoting rhizobacteria and endophytes, like Bacilli and Paenibacilli, produce a wide spectrum of volatile organic compounds (VOCs), which exhibit a high chemical diversity and manifold activities. In this work we investigated the volatilomes of Paenibacillus polymyxa DSM 32871 and M1, which were grown in four different cultivation media (NA, LB, TSA and Landy). The obtained results summarized in Table 4 show that the production of VOCs by such organisms is strain and medium dependent.

The identification of microbial volatile organic compounds (mVOCs) was performed via HS-SPME GC-MS, compared to the NIST MS 14 database and confirmed via Kovats Index. In total, 25 different volatile compounds could be identified in the headspace of P. polymyxa M1. In contrast to M1, only 20 volatile substances were detected as products of P. polymyxa DSM 32871. Interestingly, M1 exhibited the broadest array of mVOCs when grown on NA, whereas DSM 32871 produced the highest number of volatiles cultivated in TSA. Both strains produced a mixture of ketones, alcohols, alkanes, alkenes, and a variety of alkylpyrazines. The volatilomes of P. polymyxa DSM 32871 and M1 are highly overlapping with $\mathrm{n}$-hexane being the sole compound, which could only be found in DSM 32871. Five compounds were unique to M1: 2-methyl-1-propanol, 2-methylbutanenitrile, dimethyl sulfone, butyl acetate, 3-methylbutyl acetate and 2-heptanone. In comparison to other plant growth promoting rhizobacteria of the order Bacillales, such as Bacillus subtilis, Bacillus atrophaeus, Bacillus amyloliquefaciens, Bacillus velezensis, and Bacillus licheniformis [57], both P. polymyxa strains emitted a variety of alkylpyrazines. In previous studies, alkylpyrazines exhibited antibacterial, antifungal, antimycobacterial, algicidal and antiviral activities [58-61]. Additionally, 2-methyl-1-butanol, 2-heptanone and 2-ethyl-1-hexanol revealed growth inhibition against Agrobacterium tumefaciens C58 and Synechococcus sp. PCC 7942 as well as fungal pathogens, such as Phyllosticta citricarpa and Aspergillus fumigatus [62-64]. Acetoin, 2,3-butanediol and 3-methyl-1-butanol can be found in the volatilomes of DSM 32871 and M1. These compounds are known for their plant growth promoting effect and induce systemic resistance (ISR) in distinct plants [50,54,65-68]. Examples for medium specificity included 2,3-butanediol which was formed by both strains only in the Landy medium, while 1-octen-3-ol and 2-ethyl-1-hexanol have been detected specifically in the TSA-medium. Paenibacillus polymyxa is a potent producer of 2,3-butanediol which is often cogenerated by other volatile products, such as ethanol, acetoin and acetic acid together with specific exopolysaccharides [69]. In particular, 2,3-butanediol is of high commercial importance for wide industrial applications as next generation fuels and as a feedstock compound for pharmaceuticals, cosmetics and foot preservatives.

The so far known biological functions of the observed volatiles are summarized in the right part of Table $4[50,54,62,64-67,70-74]$. However, their biological effects and their underlying mode of action still need to be investigated. 


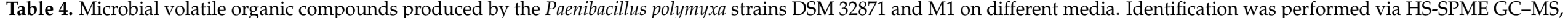
matching to the NIST Mass Spectral Database and confirmation by the Kovats Index. ${ }^{*}$ Assignment as mVOCs refers to the absence in the mVOC database [75].

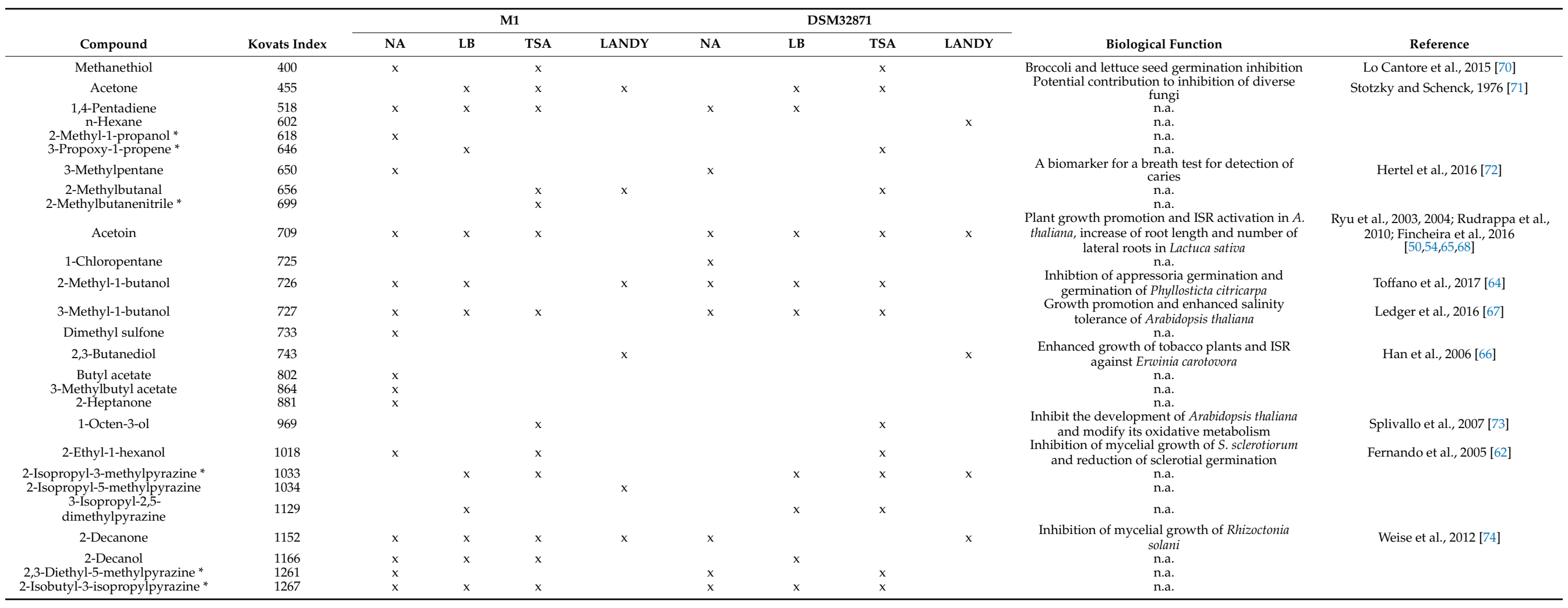




\section{Discussion}

In this work we investigated the biosynthetic potential of the P. polymyxa strains DSM 32871 and M1. Both strains produce among some other bioactive compounds three lipopeptide complexes, the fusaricidins, the polymyxins and the tridecaptins. Our efforts were focused on the mass spectrometric analysis of the fusaricidins and polymyxins formed by the DSM 32871 strain, which were compared with those produced by the well characterized M1 strain [10,11,44]. Both lipopeptide families are of high commercial interest because of their potential importance for applications both in agrobiotechnology and medicine.

The fusaricidins being the main products of DSM 32871 and M1 are known to exert potent antifungal activities. They show an unusual complexity because of manifold variations both in their peptide moiety as well as in their fatty acid part. For the reference strain M1 more than 80 variants have been reported so far [11]. Interestingly, by MALDI-TOF mass spectrometric analysis of the fusaricidin complex of strain DSM 32871 three novel series of yet unknown fusaricidins were detected specifically when cultivated in the Landy/LOP medium. Prominent mass peaks of high intensity were found for fusaricidin variants modified at the free hydroxyl group of their allo-Thr component in position 4 by esterification with an alanine residue. Small amounts of such species have previously been found also for strain M1 specifically for fusaricidin C and D [10]. Another set of novel fusaricidins was detected, which are modified by an additional $\mathrm{OH}$-group in their fatty acid part, which still remains to be precisely located.

Fusaricidins have been utilized for biocontrol of numerous fungal plant diseases [26,27,29-31]. The aim of future studies will be the purification and provision in semi/preparative scale of selected fusaricidins by high resolution separation techniques for biocontrol applications in plant biotechnology.

Another prominent lipopeptide family produced by P. polymyxa DSM 32871 and M1 are the polymyxins which are cyclic decapeptides. They are well suited to inactivate Gram-negative pathogens, such as Klebsiella, Enterobacteriaceae, A. baumannii and P. aeruginosa [44-46]. DSM 32871 produces polymyxins E (colistins), while M1 forms polymyxins P. Polymyxins were discovered in 1947 [76] and used for at least two decades as efficient antibiotics. Due to nephrotoxic and neurotoxic side effects they were taken from the market; however, recently polymyxins were retrieved again as last-resort antibiotics to counteract multiresistant super bugs $[32,37,45,46]$. High financial investment is made in several countries to optimize their structure, activities and pharmacokinetic properties with the aim to create novel efficient agents to contribute to the pertinent problem to overcome antibiotic multiresistance, which is one of the most urgent issues to protect mankind against otherwise invincible dangerous pathogens.

By MALDI-TOF mass spectrometric analysis of the polymyxin E and P complexes produced by DSM 32871 and M1 we detected modified minor polymyxin species (see Table 2), which would be worth testing therapeutically. For example, for both polymyxin species we found variants which showed the polymyxin E or P sequence, but in addition contain a residue of $146 \mathrm{Da}$ which could not yet be identified. We hypothesize that they may be glycosylated. The aim of our forthcoming studies will be to isolate and upgrade these variants in pure form by high resolution separation methodology for enabling structure elucidation and clinical testing.

Another important aspect of polymyxins is their application as biocontrol agents in agrobiotechnology to inactivate deleterious phytopathogens in order to prevent and cure plant diseases caused by Gram-negative plant pathogenic bacteria. For example, polymyxins P produced by the M1 strain were recently applied successfully against Erwinia strains [44].

In the third part of our work, we investigated the manifold volatile organic compounds (VOCs) produced by P. polymyxa strains DSM 32871 and M1. VOCs attain increasing interest concerning their influence on the plant microbiomes and the communication between their members in the rhizosphere as well as their action inside plant tissues. 
Studies have been initiated to use VOCs produced by P. polymyxa strains as biocontrol agents to inactivate phytopathogenic microorganisms and to induce systemic resistance against such pathogens [77-79]. The wide spectrum of volatiles produced by DSM 32871 and M1 is presented in Table 4. They comprise ketones, alcohols, alkanes and alkenes. A characteristic feature of different Paenibacillus species is their production of volatile pyrazine derivatives [58-61].

Among the volatiles produced by Paenibacillus polymyxa 2,3-butanediol is of particular commercial importance for wide industrial applications, such as next generation fuels and as a feedstock compound for pharmaceuticals, cosmetics and food preservatives. Downstream processing in 2,3-butane fermentation is strongly hampered by the concomitant production of exopolysaccharides which increase medium viscosity. This problem can be avoided by disruption of the gene encoding levansucrase, the major enzyme responsible for EPS biosynthesis creating a levansucrase null mutant [69]. On the other hand, extracellular polysaccharides play an important role in biofilm formation of Paenibacilli for successful colonization of plant roots in the rhizosphere. EPS are responsible for the contact between bacteria and root surfaces for effective development of plant growth promotion and biocontrol $[80,81]$.

The specific equipment of the investigated P. polymyxa strains with VOCs revealed to be strain and medium dependent. Here, the prospect of forthcoming studies is the investigation of their mechanism of action within the plant microbiome.

As a resumé of our detailed analyses of P. polymyxa strains we emphasize prospecting their potential for applications both for medical uses as well as in plant biotechnology.

\section{Materials and Methods}

\subsection{Materials}

The matrices $\alpha$-cyanohydroxycinnamic acid (CCA) and dihydroxy-benzoic acid (DHB) used for MALDI-TOF MS were obtained from Bruker (Bremen, Germany). Acetonitrile (ACN, HPLC grade) was purchased from Merck (Darmstadt, Germany), trifluoroacetic acid (TFA) from Sigma-Aldrich (Deisenhofen, Germany).

\subsection{Cultivation of Organisms}

For the preparation of surface extracts of Paenibacillus polymyxa strains DSM 32871 and M1 were grown on agar plates using three cultivation media [57]: (a) Lysogeny broth (Luria-Bertani) (LB) medium, (b) Landy medium [82] and (c) TSA medium solidified with $1.5 \%$ agar in Petri dishes for 24,48 and $72 \mathrm{~h}$ at $30^{\circ} \mathrm{C}$. In addition, liquid fermentations were carried out in $100 \mathrm{~mL}$ Erlenmeyer flasks at $30^{\circ} \mathrm{C}$ and $200 \mathrm{rpm}$ in an orbital shaker (Buehler, Germany) in the LOP and LB medium to detect products released by the strains into the culture medium. The LOP medium is a modified Landy medium which compared with the original version [82] contains higher amounts of glucose $\times \mathrm{H}_{2} \mathrm{O}(42 \mathrm{~g} / \mathrm{L})$ and Na-glutamate $\times \mathrm{H}_{2} \mathrm{O}(14 \mathrm{~g} / \mathrm{L})$.

\subsection{Sample Preparation}

In order to obtain complete profiles of bioactive peptides produced by the investigated P. polymyxa strains DSM 32871 and M1, their products were detected by MALDI-TOF MS (a) in surface extracts of cells picked either from agar plates or harvested from liquid cultures by centrifugation for 10-20 min at 15,000 rpm, (b) in culture supernatants after growth for 12; 24; 48; 72 and $96 \mathrm{~h}$ and (c) after cells disintegration by solubilization with $80 \%$ trifluoroacetic acid. For (a), a wire loop of cell material was picked, suspended in $50 \mu \mathrm{L}$ $50 \%$ acetonitrile $/ 0.1 \%$ TFA and extracted for $15 \mathrm{~min}$ by vigorous vortexing. Finally, cells were spun down at 15,000 rpm for $10 \mathrm{~min}$.

\subsection{HPLC Fractionation of the Bioactive Compounds}

An amount of $330 \mu \mathrm{L}$ of the culture filtrate of P. polymyxa DSM 32871 cultivated in the LOP medium was diluted with $660 \mu \mathrm{L} \mathrm{0.1 \%} \mathrm{TFA.} \mathrm{This} \mathrm{sample} \mathrm{was} \mathrm{applied} \mathrm{to} \mathrm{a} 300 \mathrm{SB}-\mathrm{C} 8$ 
Zorbax column $(4.6 \times 250 \mathrm{~mm} ; 5 \mu \mathrm{m})$ and fractionated by reversed-phase HPLC using an Agilent (1200 series) instrument (Agilent Technologies, Waldbronn, Germany). Bioactive compounds were eluted by a two-step gradient from 0 to $70 \%$ eluent $B$ in $70 \mathrm{~min}$ and from 70 to $95 \%$ eluent $B$ in $5 \mathrm{~min}$ (70-75 $\mathrm{min}$ ) followed by isocratic elution at $95 \%$ eluent $B$ for $10 \mathrm{~min}$ at a flow rate of $0.5 \mathrm{~mL} / \mathrm{min}$. Eluent A was $0.1 \%$ TFA in water; eluent B was $99.9 \%$ $\mathrm{ACN} / 0.1 \%$ TFA. Fractions of $1 \mathrm{~mL}$ were collected and evaporated to dryness in a SpeedVac evaporator (Uniequip, Martinsried, Germany). The dried material was dissolved in $30 \mu \mathrm{L}$ $50 \%$ aqueous ACN/0.1 TFA and tested mass spectrometrically.

\subsection{Profiling of Bioactive Peptides by MALDI-TOF MS}

Bioactive peptides of P. polymyxa DSM 32871 and M1 were detected and identified by MALDI-TOF MS, as outlined previously [11,13,58]. A Bruker Autoflex Speed TOF/TOF mass spectrometer (Bruker Daltonik, Bremen, Germany) was used with Smartbeam laser technology using a $1 \mathrm{kHz}$ frequency-tripled Nd-YAG laser $\left(\lambda_{\mathrm{ex}}=355 \mathrm{~nm}\right)$. Samples $(2 \mu \mathrm{L})$ of surface extracts and culture supernatants were mixed with $2 \mu \mathrm{L}$ matrix solution (a saturated solution of $\alpha$-hydroxy-cinnamic acid in 50\% aqueous ACN containing $0.1 \%$ TFA), spotted on the target, air dried and measured. Mass spectra were obtained by positive-ion detection in reflector mode. Monoisotopic masses were obtained. Parent ions were detected with a resolution of 10,000 . Sequence analysis of the lipopeptide products was performed by LIFT-MALDI-TOF/TOF mass spectrometry in laser induced decay (LID) mode [56]. The product ions in the LIFT-TOF/TOF fragment spectra were obtained with a resolution of 1000.

The mass spectrometry results did not allow optical isomers to be distinguished. Therefore, the configurations of the amino acid components were not indicated.

\subsection{Identification of Microbial Volatiles Using GC-MS}

Paenibacillus polymyxa strains DSM 32871 and M1 were grown in $20 \mathrm{~mL}$ headspace vials $(75.5 \times 22.5 \mathrm{~mm}$; Chromtech, Idstein, Germany) filled with $8 \mathrm{~mL}$ of (a) nutrient agar (Sifin Diagnostic GmbH, Berlin, Germany), (b) Lysogeny broth (Luria-Bertani) (LB) medium, (c) Landy medium [82] and (d) TSA medium. Equal distribution was assured by parallel application of cell material in three vials per organism. After $24 \mathrm{~h}$ of incubation at $30^{\circ} \mathrm{C}$, the volatiles accumulating inside the vials were measured by headspace solid-phase microextraction gas chromatography-mass spectrometry (HS-SPME GC-MS). Compound separation and detection was performed on a system combining a gas chromatograph 7890A with a quadrupol mass spectrometer 5975C (Agilent Technologies, Waldbronn, Germany). A SPME fiber consisting of divinylbenzene/carboxen/polydimethylsiloxane (DVB/CAR/PDMS) was used for sampling (Sigma-Aldrich, St. Louis, MO, USA). HS samples were separated in a (5\%-phenyl)methylpolysiloxane column $(60 \mathrm{~m} \times 0.25 \mathrm{~mm}$ i.d.; $0.25 \mu \mathrm{m}$ film thickness; DB-5MS; Agilent Technologies, Waldbronn, Germany). Subsequently, electron ionization with $70 \mathrm{eV}$ and detection in the mass range 25-350 Da were performed. The fiber was desorbed at $200{ }^{\circ} \mathrm{C}$ for $8 \mathrm{~min}$ to eliminate potential residues before initial measurements. The inlet temperature was set to $270{ }^{\circ} \mathrm{C}$. The temperature gradient of the column was maintained at $70{ }^{\circ} \mathrm{C}$ for $1.5 \mathrm{~min}$, raised to $200{ }^{\circ} \mathrm{C}$ at a rate of $16^{\circ} \mathrm{C} / \mathrm{min}$ and finally kept at $200{ }^{\circ} \mathrm{C}$ for $0.5 \mathrm{~min}$. The helium flow rate was adjusted to $1.2 \mathrm{~mL} / \mathrm{min}$. For identification of the volatiles the received spectra were matched to the NIST Mass Spectral Database.

Supplementary Materials: The following are available online at https: / www.mdpi.com/article/ 10.3390/pathogens10111485/s1, Figure S1: MALDI-TOF mass spectra of the fusaricidins in surface extracts and culture filtrates of P. polymyxa DSM 32871 and M1, Figure S2: MALDI-TOF mass spectra of the products found in fractions 22 until 31 of the HPLC fractionation of the culture filtrate of DSM 32871, Figure S3: Upper part of the LIFT-MALDI-TOF/TOF product ion spectra of fusaricidin $\mathrm{A}\left([\mathrm{M}+\mathrm{H}]^{+}=883.74\right)(\mathrm{A})$ and its derivatives with molecular masses $[\mathrm{M}+\mathrm{H}+71]^{+}=954.63$ and $[\mathrm{M}+\mathrm{H}+16]^{+}=899.43$, respectively, in the range from 280 Da up to the parent ion. 
Author Contributions: K.D., E.S., P.M. and J.V. designed and developed the experimental strategy and the concept of the manuscript. E.S., P.M., K.D. and S.H. performed the microbiological work (strain management and sample preparation). J.V., S.H. and J.J. performed the generation, evaluation and presentation of the mass spectrometric data. P.M. studied the volatilomes of the tested P. polymyxa strains. S.H. performed the HPLC analysis. J.V. and P.M. wrote the manuscript. P.L., T.C. and G.B. were involved in preparation and discussion of the manuscript. All authors have read and agreed to the published version of the manuscript.

Funding: Funding was received from the European Union's Horizon 2020 research and innovation programme under the Marie Sklodowska-Curie grant agreement No 676480.

Institutional Review Board Statement: Not applicable.

Informed Consent Statement: Not applicable.

Data Availability Statement: The data presented in this article are available on request from the corresponding author.

Conflicts of Interest: The authors declare no conflict of interest.

\section{References}

1. Cochrane, S.A.; Vederas, J.C. Lipopeptides from Bacillus and Paenibacillus spp.: A gold mine of antibiotic candidates. Med. Res. Rev. 2016, 36, 4-31. [CrossRef] [PubMed]

2. Aleti, G.; Sessitsch, A.; Brader, G. Genome mining: Prediction of lipopeptides and polyketides from Bacillus and related Firmicutes. Comput. Struct. Biotechnol. 2015, 13, 192-203. [CrossRef]

3. Xie, J.; Shi, H.; Du, Z.; Wang, T.; Liu, X.; Chen, S. Comparative genomic and functional analysis reveal conservation of plant growth promoting traits in Paenibacillus polymyxa and its closely related species. Sci. Rep. 2016, 6, 21329. [CrossRef] [PubMed]

4. Zhao, X.; Kuipers, O.P. Identification and classification of known and putative antimicrobial compounds produced by a wide variety of Bacillales species. BMC Genom. 2016, 17, 882. [CrossRef] [PubMed]

5. Kajimura, Y.; Kameda, M. Fusaricidin A, a new depsipeptide antibiotic produced by Bacillus polymyxa KT-8. Taxonomy, fermentation, isolation, structure elucidation and biological activity. J. Antibiot. 1996, 49, 129-135. [CrossRef]

6. Kajimura, Y.; Kameda, M. Fusaricidin B, C and D, new depsipeptide antibiotics produced by Bacillus polymyxa KT-8. Isolation, structure elucidation and biological activity. J. Antibiot. 1997, 50, 220-228. [CrossRef]

7. Kurusu, K.; Ohba, K.; Arai, T.; Fukushima, K. New peptide antibiotics LI-F03, F04, F05, F07 and F08 produced by Bacillus polymyxa. Isolation and characterization. J. Antibiot. 1997, 40, 1506-1514. [CrossRef]

8. Kuroda, J.; Fukai, J.; Konishi, M.; Ono, J.; Kurusu, K.; Nomura, T. Li-F antibiotics, family of antifungal cyclic depsipeptides produced by Bacillus polymyxa L-1129. Heterocycles 2000, 53, 1533-1549. [CrossRef]

9. Kuroda, J.; Fukai, J.; Nomura, T. Collision-induced dissociation of ring-opened cyclic depsipeptides with a guanidino group by electrospray ionization trap mass spectrometry. J. Mass Spectrom. 2001, 36, 30-37. [CrossRef]

10. Vater, J.; Niu, B.; Dietel, K.; Borriss, R. Characterization of novel fusaricidins produced by Paenibacillus polymyxa-M1 using MALDI-TOF mass spectrometry. J. Am. Soc. Mass Spectrom. 2015, 26, 1548-1557. [CrossRef]

11. Vater, J.; Herfort, S.; Doellinger, J.; Weydmann, M.; Dietel, K.; Faetke, S.; Lasch, P. Fusaricidins from Paenibacillus polymyxa M-1, a family of lipohexapeptides of unusual complexity-A mass spectrometric study. J. Mass Spectrom. 2017, 52, 7-15. [CrossRef] [PubMed]

12. Qiu, S.; Avula, B.; Guan, S.; Ravu, R.R.; Wang, M.; Zhao, J.; Khan, I.A.; Hinchee, M.; Li, X.-C. Identification of fusaricidins from the antifungal microbial strain Paenibacillussp. MS2379 using ultra-high performance liquid chromatography coupled to quadrupole time-of-flight mass spectrometry. J. Chromatogr. A 2019, 1586, 91-100. [CrossRef] [PubMed]

13. Vater, J.; Herfort, S.; Doellinger, J.; Weydmann, M.; Borriss, R.; Lasch, J. Genome mining of the lipopeptide biosynthesis of Paenibacillus polymyxa E681 in combination with mass spectrometry: Discovery of the lipoheptapeptide paeniloheptin. ChemBioChem 2018, 19, 744-753. [CrossRef] [PubMed]

14. Velkov, T.; Roberts, K.D.; Li, J. Rediscovering the octapeptins. Nat. Prod. Rep. 2017, 34, 295-309. [CrossRef]

15. Sogn, J.A. Structure of the peptide antibiotic polypeptin. J. Med. Chem. 1976, 19, 1228-1231. [CrossRef] [PubMed]

16. Qian, C.-D.; Liu, T.-Z.; Zhou, S.-L.; Ding, R.; Zhao, W.-P.; Li, O.; Wu, X.-C. Identification and functional analysis of gene cluster involvement in biosynthesis of the cyclic lipopeptide antibiotic pelgipeptin produced by Paenibacillus elgii. BMC Microbiol. 2012, 12, 197. [CrossRef] [PubMed]

17. Velkov, T.; Thompson, P.E.; Nation, R.L.; Li, J. Structure-activity relationships of polymxin antibiotics. J. Med. Chem. 2010, 53, 1898-1916. [CrossRef] [PubMed]

18. Kato, T.; Hinoo, H.; Shoji, J. The structure of tridecaptin A (studies on antibiotics from the genus Bacillus. XXIV). J. Antibiot. 1978, 31, 652-661. [CrossRef]

19. Kato, T.; Sakazaki, R.; Hinoo, H.; Shoji, J. The stuctures of tridecaptins B and C (studies on antibiotics from the genus Bacillus. XXV). J. Antibiot. 1979, 32, 305-312. [CrossRef] 
20. Cochrane, S.A.; Lohans, C.T.; van Belkum, M.J.; Bels, M.A.; Vederas, J.C. Studies on tridecapeptin B(1), a lipopeptide with activity against multidrug resistant Gram-negative bacteria. Org. Biomol. Chem. 2015, 13, 6073-6081. [CrossRef] [PubMed]

21. Guo, Y.; Huang, E.; Yuan, C.; Zhang, L.; Yousef, A.E. Isolation of a Paenibacillus sp. strain and structural elucidation of its broad-spectrum lipopeptide antibiotic. Appl. Environ. Microbiol. 2012, 78, 3156-3165. [CrossRef] [PubMed]

22. Huang, E.; Guo, Y.; Yousef, A.E. Biosynthesis of the new broad-spectrum lipopeptide antibiotic paenibacterin in Paenibacillus thiaminolyticus OSY-SE. Res. Microbiol. 2014, 165, 243-251. [CrossRef] [PubMed]

23. Lal, S.; Tabacchioni, S. Ecology and biotechnological potential of Paenibacillus polymyxa: A minireview. Ind. J. Microbiol. 2009, 49, 2-10. [CrossRef] [PubMed]

24. Eastman, A.W.; Heinrichs, D.E.; Yuan, Z.C. Comparative and genetic analysis of four sequenced Paenibacillus polymyxa genomes reveals a diverse metabolism and conservation of genes relevant to plant-growth promotion and competitiveness. BMC Genom. 2014, 15, 851. [CrossRef] [PubMed]

25. Ali, M.A.; Lou, Y.; Hafeez, R.; Li, X.; Hossein, A.; Xie, T.; Lin, L.; Li, B.; Yin, Y.; Yan, J.; et al. Functional analysis of genome mining reveal high potential of biocontrol and plant growth promotion in nodule-inhabiting bacteria within Paenibacillus polymyxa complex. Front. Microbiol. 2021, 11, 618601. [CrossRef] [PubMed]

26. Mousa, W.K.; Shearer, C.R.; Limay-Rios, V.; Zhou, T.; Raizada, M.N. Bacterial endophytes from wild maize suppress Fusarium graminearum in modern maize and inhibit mycotoxin accumulation. Front. Plant Sci. 2015, 6, 805. [CrossRef] [PubMed]

27. Khan, M.S.; Gao, J.; Chen, X.; Zhang, M.; Yang, F.; Du, Y.; Moe, T.S.; Munir, I.; Xue, J.; Zhang, X. Isolation and characterization of plant growth-promoting endophytic bacteria Paenibacillus polymyxa SK1 from Lilium lancifolium. BioMed Res. Int. 2020, 2020, 8650957. [CrossRef]

28. Niu, B.; Rueckert, C.; Blom, J.; Wang, Q.; Borriss, R. The genome of the plant growth promoting rhizobacterium Paenibacillus polymyxa M-1 contains nine sites dedicated for nonribosomal synthesis of lipopeptides and polyketides. J. Bacteriol. 2011, 193, 5862-5863. [CrossRef] [PubMed]

29. Li, Y.; Chen, S. Fusaricidin produced by Paenibacillus polymyxa WLY78 induces systemic resistance against Fusarium wilt of cucumber. Int. J. Mol. Sci. 2019, 20, 5240. [CrossRef]

30. Beatty, P.H.; Jensen, S.E. Paenibacillus polymyxa produces fusaricidin-type antifungal antibiotics active against Leptoshaeria maculans, the causative agent of blackleg disease of canola. Can. J. Microbiol. 2002, 48, 159-169. [CrossRef]

31. Abdallah, Y.; Yang, M.; Zhang, M.; Masum, M.M.I.; Ogunyemi, S.O.; Hossein, A.; An, Q.; Yan, C.; Li, B. Plant growth promotion and suppression of bacterial leaf blight in rice by Paenibacillus polymyxa Sx3. Lett. Appl. Microbiol. 2019, 68, 423-429. [CrossRef] [PubMed]

32. Velkov, T.; Roberts, K.D.; Nation, R.L.; Wang, J.; Thompson, P.E.; Li, J. Teaching old polymyxins new tricks: New-generation lipopeptides targeting Gram-negative superbugs. ACS Chem. Biol. 2014, 9, 1172-1177. [CrossRef]

33. Suzuki, T.; Inouye, H.; Fujikawa, K.; Suketa, Y. Studies on the chemical structure of colistin. J. Biochem. 1963, 54, 25-33. [CrossRef] [PubMed]

34. Suzuki, T.; Hayashi, K.; Fujikama, K.; Tsukamoto, K. The chemical structure of polymyxin E: The identities of polymyxin E1 with colistin A and of polymyxin E2 with colistin B. J. Biochem. 1965, 57, 226-227. [CrossRef]

35. Govaerts, C.; Rozenski, J.; Orwa, J.; Roets, E.; Van Schepdael, A.; Hoogmartens, J. Mass spectrometric fragmentation of cyclic peptides belonging to the polymyxin and colistin antibiotics studied by ion trap and quadrupole/orthogonal-acceleration time-of-flight technology. Rapid Commun. Mass Spectrom. 2002, 16, 823-833. [CrossRef] [PubMed]

36. Kimura, Y.; Murai, E.; Fujisawa, M.; Tatsuki, T.; Nobue, F. Polymyxin P, new antibiotic of polymyxin group. J. Antibiot. 1969, 22, 449-450. [CrossRef]

37. Brown, P.; Dawson, M.J. Development of new polymyxin derivatives for multi-drug resistant Gram-negative infections. J. Antibiot. 2017, 70, 386-394. [CrossRef] [PubMed]

38. Govaerts, C.; Orwa, J.; Van Schepdael, A.; Roets, E.; Hoogmartens, J. Characterization of the polymyxin series by liquid chromatography electrospray ionization ion trap tandem mass spectrometry. J. Pept. Sci. 2002, 7, 45-55. [CrossRef]

39. Govaerts, C.; Orwa, J.; Van Schepdael, A.; Roets, E.; Hoogmartens, J. Liquid chromatography-ion trap tandem 39mamass spectrometry for the characterization of polypeptide antibiotics of the colistin series in commercial samples. J. Chromatogr. A 2002, 976, 65-78. [CrossRef]

40. Orwa, J.; Govaerts, C.; Gevers, K.; Roets, E.; Van Schepdael, A.; Hoogmartens, J. Study of the stability of polymyxins B1, E1 and E2 in aqueous solution using liquid chromatography and mass spectrometry. J. Pharm. Biomed. Anal. 2002, 29, 203-212. [CrossRef]

41. Shaheen, M.; Li, J.; Ross, A.C.; Vederas, J.C.; Jensen, S.E. Paenibacillus polymyxa PK31 produces variants of polymyxin B-type antibiotics. Chem. Biol. 2011, 18, 1640-1648. [CrossRef] [PubMed]

42. Tambadou, F.; Caradec, T.; Gagez, A.-L.; Bonnet, A.; Sopena, V.; Bridiau, N.; Thiéry, V.; Didelot, S.; Barthélémy, C.; Chevrot, R. Characterization of the colistin (polymyxin E1 andE2) biosynthetic gene cluster. Arch. Microbiol. 2015, 197, 521-532. [CrossRef] [PubMed]

43. Choi, S.-K.; Park, S.-Y.; Kim, R.; Kim, S.-B.; Lee, C.-H.; Kim, J.F.; Park, S.-H. Identification of a polymyxin synthetase gene cluster of Paenibacillus polymyxa and heterologous expression of the gene in Bacillus subtilis. J. Bacteriol. 2009, 191, 3350-3358. [CrossRef]

44. Niu, B.; Vater, J.; Rueckert, C.; Blom, J.; Lehmann, M.; Ru, J.-J.; Chen, X.-H.; Wang, Q.; Borriss, R. Polymyxin P is the active principle in suppressing phytopathogenic Erwinia spp. by the biocontrol rhizobacterium Paenibacillus polymyxa M-1. BMC Microbiol. 2013, 13, 137. [CrossRef] [PubMed] 
45. Vaara, M. Polymyxins and their potential next generation as therapeutic antibiotics. Front. Microbiol. $2019,10,1689$. [CrossRef] [PubMed]

46. Nang, S.C.; Azad, M.A.K.; Velkov, T.; Zhou, Q.; Li, J. Rescuing the last-line polymyxins: Achievements and challenges. Pharmacol. Rev. 2021, 73, 679-728. [CrossRef]

47. Audrain, B.; Farag, M.A.; Ryu, C.M.; Ghigo, J.M. Role of bacterial volatile compounds in bacterial biology. FEMS Microbiol. Rev. 2015, 39, 222-233. [CrossRef] [PubMed]

48. Kanschiswamy, C.N.; Malnoy, M.; Maffei, M.E. Chemical diversity of microbial volatiles and their potential for plant growth and productivity. Front. Plant Sci. 2015, 6, 151. [CrossRef]

49. Kai, M. Diversity and distribution of volatile secondary metabolites throughout Bacillus subtilis isolates. Front. Microbiol. 2020, 11, 559. [CrossRef]

50. Ryu, C.-M.; Farag, M.A.; Hu, C.-H.; Reddy, M.S.; Wei, H.-X.; Pare, P.W.; Kloepper, J.W. Bacterial volatiles promote growth in Arabidopsis. Proc. Natl. Acad. Sci. USA 2003, 100, 1017-1026. [CrossRef]

51. Asari, S.; Matzen, S.; Petersen, M.A.; Bejai, S.; Meijer, J. Multiple effects of Bacillus amyloliquefaciens volatile compounds: Plant growth promotion and growth inhibition of phytopathogens. FEMS Microbiol. Ecol. 2016, 92, 070. [CrossRef] [PubMed]

52. Wu, Y.; Zhou, J.; Li, C.; Ma, Y. Antifungal and plant growth promotion activity of volatile organic compounds produced by Bacillus amyloliquefaciens. Microbiol. Open 2018, 8, e813. [CrossRef]

53. Kloepper, J.W.; Ryu, C.-M.; Zhang, S. Induced systemic resistance and promotion of plant growth by Bacillus spp. Phytopathology 2004, 94, 1259-1266. [CrossRef] [PubMed]

54. Ryu, C.-M.; Farag, M.A.; Hu, C.-H.; Reddy, M.S.; Klöpper, J.W.; Pare, P.W. Bacterial volatiles induce systemic resistance in Arabidopsis. Plant Physiol. 2004, 134, 1017-1026. [CrossRef] [PubMed]

55. Farag, M.A.; Ryu, C.-M.; Sumner, L.W.; Pare, P.W. GC-MS SPME profiling of rhizobacterial volatiles reveals prospective inducers of growth promotion and induced systemic resistance in plants. Phytochemistry 2006, 67, 2262-2268. [CrossRef]

56. Suckau, D.; Resemann, A.; Schuerenberg, M.; Hufnagel, P.; Franzen, J.; Holle, A. A novel MALDI LIFT-TOF/TOF mass spectrometer for proteomics. Anal. Bioanal. Chem. 2003, 376, 952-965. [CrossRef]

57. Mülner, P.; Schwarz, E.; Dietel, K.; Junge, H.; Herfort, S.; Weydmann, M.; Lasch, P.; Cernava, T.; Berg, G.; Vater, J. Profiling for bioactive peptides and volatiles of plant growth promoting strains of the Bacillus subtilis complex of industrial relevance. Front. Microbiol. 2020, 11, 1432. [CrossRef]

58. Ferreira, S.B.; Kaiser, C.R. Pyrazine derivatives: A patent review (2008-present). Expert Opin. Ther. Pat. 2012, 22, 1033-1151. [CrossRef]

59. Haidar, R.; Roudet, J.; Bonnard, O.; Dufour, M.C.; Corio-Costet, M.F.; Fert, M.; Gautier, P.; Deschamps, A.; Fermaud, M. Screening and modes of action of antagonistic bacteria to control the fungal pathogen Phaeomoniella chlamydospora involved in grapevine trunk diseases. Microbiol. Res. 2016, 192, 172-184. [CrossRef]

60. Kusstatscher, P.; Cernava, T.; Liebminger, S.; Berg, G. Replacing conventional decontamination of hatching eggs with a natural defense strategy based on antimicrobial volatile pyrazines. Sci. Rep. 2017, 7, 1-8. [CrossRef]

61. Mülner, P.; Wagner, P.; Bergna, A.; Sarajlic, D.; Gstöttenmayr, B.; Dietel, K.; Grosch, R.; Cernava, T.; Berg, G. Microbiota associated with sclerotia of soilborne fungal pathogens-A novel source of biocontrol agents producing bioactive volatiles. Phytobiom. J. 2019, 3, 125-136. [CrossRef]

62. Fernando, W.G.D.; Ramarathnam, R.; Krishnamoorthy, A.S.; Savchuk, S.C. Identification and use of potential bacterial organic antifungal volatiles in biocontrol. Soil Biol. Biochem. 2005, 37, 955-964. [CrossRef]

63. Popova, A.A.; Koksharova, O.A.; Lipasova, V.A.; Zaitseva, J.V.; Katkova-Zhukotskaya, O.A.; Eremina, S.I.; Mironov, A.S.; Chernin, L.S.; Khmel, I.A. Inhibitory and toxic effects of volatiles emitted by strains of Pseudomonas and Serratia on growth and survival of selected microorganims, Caenorhabditis elegans and Drosophila melanogaster. Biomed. Res. Int. 2014, 2014, 125704. [CrossRef]

64. Toffano, L.; Fialho, M.B.; Pascholati, S.F. Potential of fumigation of orange fruits with volatile organic compounds produced by Saccharomyces cerevisiae to control citrus black spot disease at postharvest. Biol. Control. 2017, 108, 77-82. [CrossRef]

65. Fincheira, P.; Venthur, H.; Mutis, A.; Parada, M.; Quirot, A. Growth promotion of Lactuca sativa in response to volatile organic compounds emitted from diverse bacterial species. Microbiol. Res. 2016, 193, 39-47. [CrossRef]

66. Han, S.H.; Lee, S.J.; Moon, J.H.; Park, K.H.; Yang, K.Y.; Cho, B.H.; Kim, K.Y.; Kim, Y.W.; Lee, M.C.; Anderson, A.J.; et al. GacS-dependent production of 2R, 3R butanediol by Pseudomonas chlororaphis 06 is a major determinant for eliciting resistance against Erwinia carotovora but not against Pseudomonas syringae pv. Tabaci. Mol. Plant Microbe Interact. 2006, 19, 924-930. [CrossRef]

67. Ledger, T.; Rojas, S.; Timmermann, T.; Pinedo, I.; Poupin, M.J.; Garrido, T.; Richter, P.; Tamayo, J.; Donoso, R. Volatile-mediated effects predominate in Paraburkholderia phytofirmans growth promotion and salt stress tolerance of Arabidopsis thaliana. Front. Microbiol. 2016, 7, 1838. [CrossRef] [PubMed]

68. Rudrappa, T.; Biedrzycki, M.L.; Kunjeti, S.G.; Donofrio, N.M.; Czymmek, K.J.; Paré, P.W.; Bais, H.P. The rhizobacterial elicitor acetoin induces systemic resistance in Arabidopsis thaliana. Commun. Integr. Biol. 2010, 3, 130-138. [CrossRef] [PubMed]

69. Okonkwo, C.C.; Ujor, V.; Cornish, K.; Ezeji, T.C. Inactivation of the levansucrase gene in Paenibacillus polymyxa DSM 365 diminishes exopolysaccharide biosynthesis during 2,3-butanediol fermentation. Appl. Environ. Microbiol. 2020, 86, e00196-20. [CrossRef]

70. Lo Cantore, P.; Giorgio, A.; Iacobellis, N.S. Bioactivity of volatile organic compounds produced by Pseudomonas tolaasii. Front. Microbiol. 2015, 6, 1082. [CrossRef]

71. Stotzky, G.; Schenk, S. Volatile organic compounds and microorganisms. CRC Crit. Rev. Microbiol. 1976, 4, 333-382. [CrossRef] 
72. Hertel, M.; Preissner, R.; Gilissen, B.; Schmidt-Westhausen, A.M.; Paris, S.; Preissner, S. Detection of signature volatiles for cariogenic microorganisms. Eur. J. Clin. Microbiol. Infect. Dis. 2016, 35, 235-244. [CrossRef] [PubMed]

73. Splivallo, R.; Novero, M.; Bertea, C.M.; Bossi, S.; Bonfante, P. Truffle volatiles inhibit growth and induce an oxidative burst in Arabidopsis thaliana. New Phytol. 2007, 175, 417-424. [CrossRef]

74. Weise, T.; Kai, M.; Gummesson, A.; Troeger, A.; von Reuß, S.; Piepenborn, S.; Kosterka, F.; Sklorz, M.; Zimmermann, R.; Francke, W.; et al. Volatile organic compounds produced by the phytopathogenic bacterium Xanthomonas campestris pv. vesicatoria 85-10. Beilstein J. Org. Chem. 2012, 8, 579-596. [CrossRef]

75. Lemfack, M.C.; Gohlke, B.-O.; Toguem, S.M.; Preissner, S.; Piechulla, B.; Preissner, R. mVOC 2.0: A database of microbial volatiles. Nucleic Acids Res. 2018, 46, D1261-D1265. [CrossRef]

76. Stansly, P.G.; Schlosser, M.E. Studies on polymyxin: Isolation and identification of Bacillus polymyxa and differentiation of polymyxin from certain known antibiotics. J. Bacteriol. 1947, 54, 549-556. [CrossRef]

77. Rybakova, D.; Rack-Wetzlinger, U.; Cernava, T.; Schaefer, A.; Schmuck, M.; Berg, G. Aerial warfare: A volatile dialogue between the plant pathogen Verticillium longisporum and its antagonist Paenibacillus polymyxa. Front. Plant Sci. 2017, 8, 1294. [CrossRef] [PubMed]

78. Cheng, W.; Yang, J.; Nie, Q.; Huang, D.; Yu, C.; Zheng, L.; Cai, M.; Thomashow, L.S.; Weller, D.M.; Yu, Z.; et al. Volatile organic compounds from Paenibacillus polymyxa KM2501-1 control Meloidogyne incognita by multiple strategies. Sci. Rep. 2017, 7, 16213. [CrossRef]

79. Lee, B.; Farag, M.A.; Park, H.B.; Kloepper, J.W.; Lee, S.H.; Ryu, C.-M. Induced resistance by a long-chain bacterial volatile: Elicitation of plant systemic defense by a C13 volatile produced by Paenibacillus polymyxa. PLoS ONE 2012, 7, e48744. [CrossRef] [PubMed]

80. Yegorenkova, I.V.; Tregubova, K.V.; Krasov, A.I.; Evseeva, N.V.; Matora, L.Y. Effect of exopolysaccarides of Paenibacillus polymyxa rhizobacteria on physiological and morphological variables of wheat seedlings. J. Microbiol. 2021, 59, 729-735. [CrossRef]

81. He, X.; Li, Q.; Wang, N.; Chen, S. Effects of an EPS biosynthesis gene cluster of Paenibacillus polymyxa WLY78 on biofilm formation and nitrogen fixation under aerobic conditions. Microorganisms 2021, 9, 289. [CrossRef] [PubMed]

82. Landy, M.; Warren, G.H.; Rosenman, S.B.; Colio, L.G. Bacillomycin; an antibiotic from Bacillus subtilis active against pathogenic fungi. Proc. Soc. Exp. Biol. Med. 1948, 67, 539-541. [CrossRef] [PubMed] 